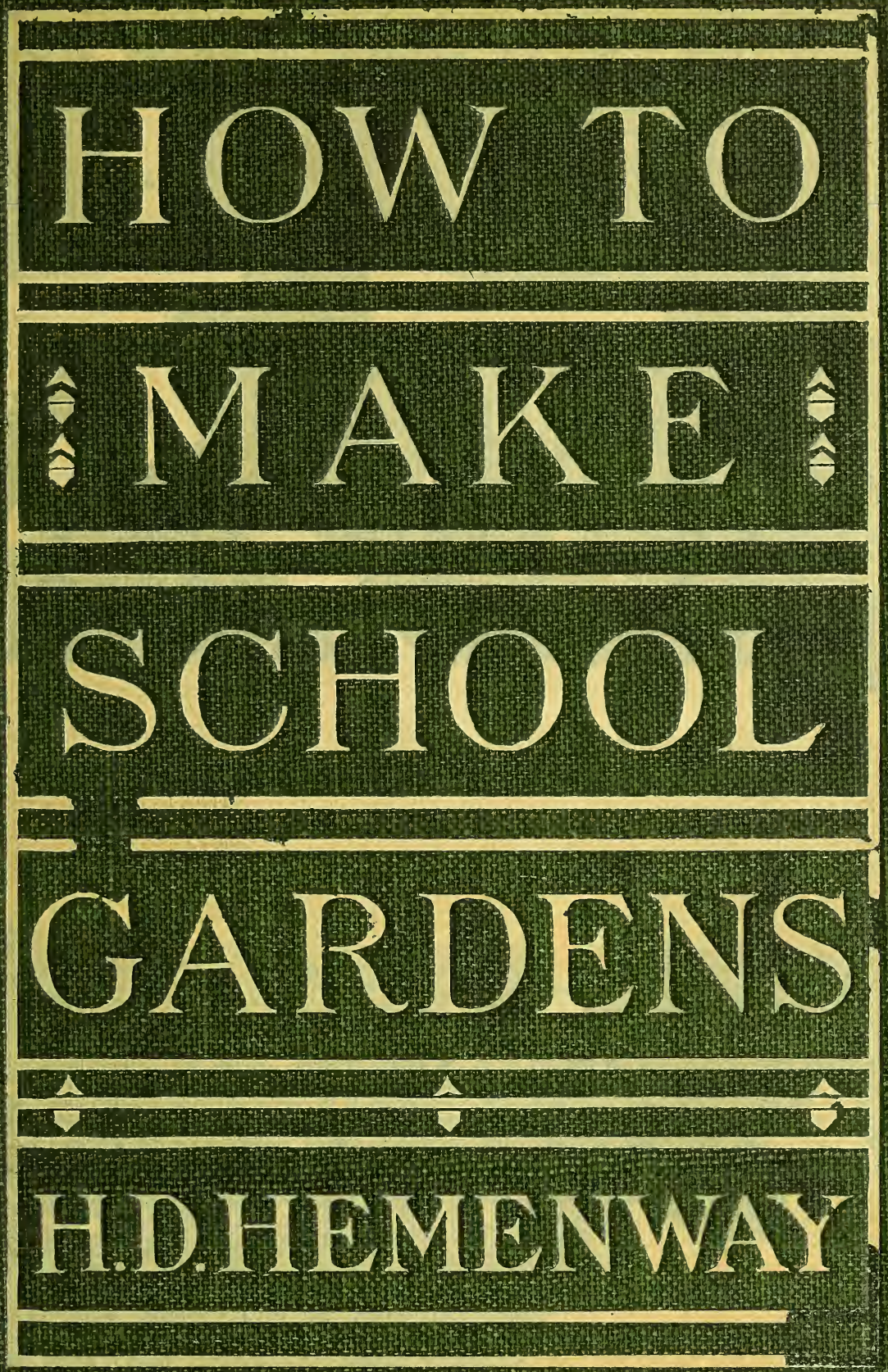







How to Make School Gardens 




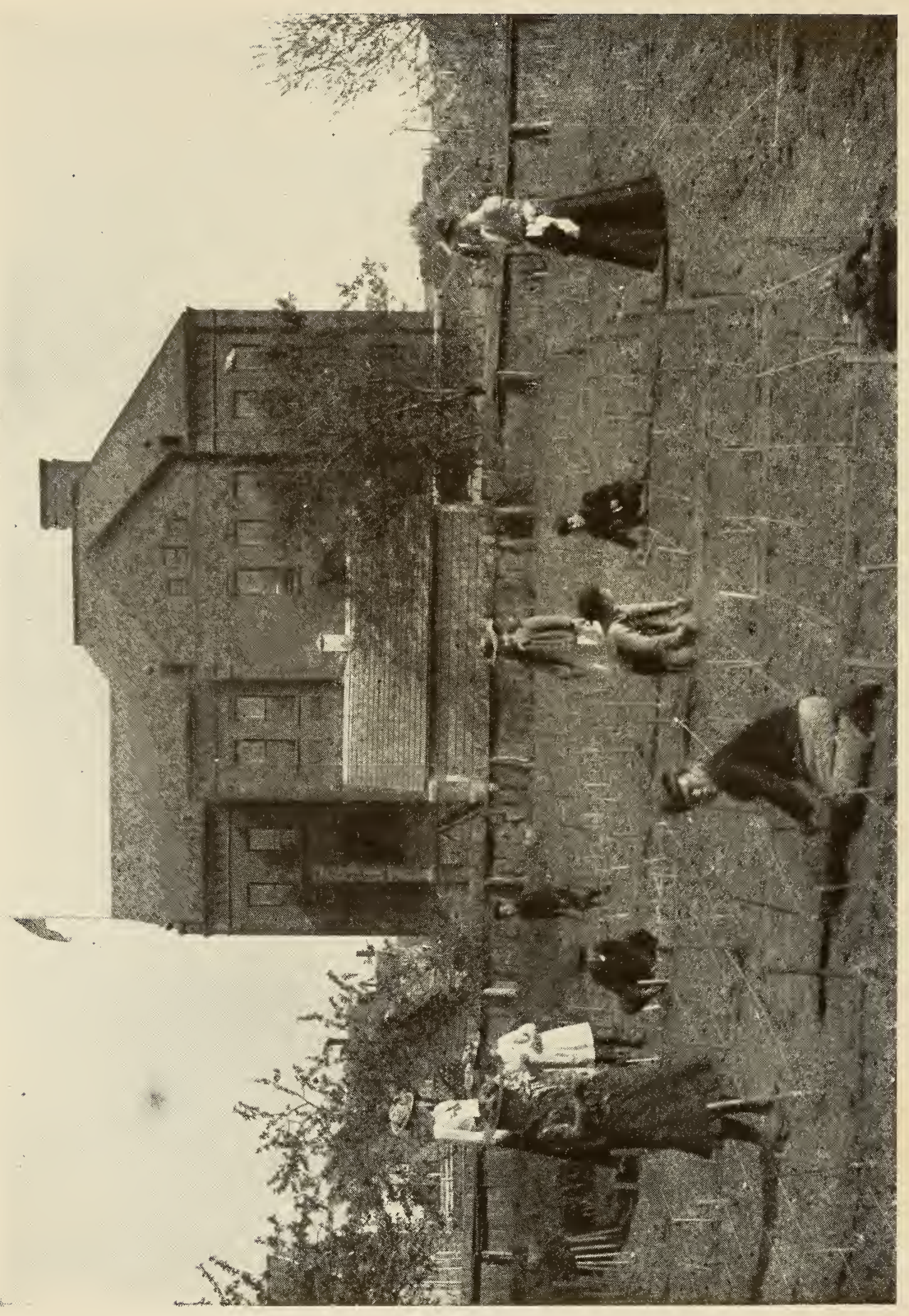

엉

它

园兑

世

茨

ค

4

(5)

里

I

II

O

b

恣 


\section{$5 B$}

55

$45 \times$ HOW TO MAKE 1903 SCHOOL GARDENS HORT

A MANUAL FOR TEACHERS AND PUPILS

BY

H. D. HEMENWAY, B. S.

Director of

Hartford School of Horticulture

IIlustrated

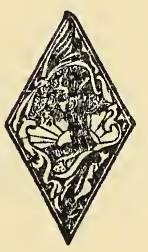

NEW YORK

DOUBLEDAY, PAGE \& COMPANY I 903 
Copyright, 1903, by Doubleday, Page \& Company

Published, May, rgo3 


\section{CONTENTS}

Introduction
Chapter
I. How to Make a School Garden





\section{LIST OF ILLUSTRATIONS}

Marking Off the Garden at Hyannis

(Mass.) Normal School-Second

Grade Children . . . Frontispiece

FACING PAGE

All Staked Ready for Planting . • . 4

Plan for Development of Grounds, Oakdale

School, East Dedham, Mass. . . 8

Preparing the Ground, Whittier School,

Hampton, Va. $\quad$. $\quad$. $\quad$ - $\quad$ I4

7I Gardens, Io x I70 Feet, National Cash

Register Company, Dayton, Ohio . $\quad 24$

Receiving Directions . . • . 24

His Own Raising • • • • • 44

School-Garden Exhibit, School of Horticulture,

Hartford, Conn. . . . . . 60

A School Garden in the Business Centre of

Cleveland-Rockwell School . . . 80

The Fun of Making a Garden. "The Chil-

dren Tackled the Soil with Such Weapons As They Could Muster" . . . 80

How to Make School Gardens (cut off) 



\section{PREFACE}

This little manual has grown out of the experience of the author in children's garden work, and is the answer to the many inquiries which are received from various points all over the country from persons who are enthusiastic and realize the purpose and advantages of the schoolgarden movement, but who have not had the agricultural advantages and training to understand the best methods of making and conducting a garden so as to get good results from an agricultural and horticultural standpoint. It is hoped that this little book will be an inspiration to beginners in the school-garden movement, and an aid to those who already have school and children's gardens, so that they can obtain the best results from agricultural, esthetic and educational stand- 
points, and so that they can better train the head, the heart and the hand.

The first chapters explain something of the development of the school-garden movement and how to make a school garden, while the remaining chapters are lessons in garden work. It is hoped these simple lessons will be of value; but, as every locality is different and the climatic and soil conditions vary, it may be found necessary to vary the directions some, the crops raised, and the size of the gardens, the latter of necessity depending upon the size of the grounds.

$$
\text { H. D. Hemenway. }
$$

School of Horticulture, Hartford, Conn., I903. 


\section{INTRODUCTION}

THE idea of having a garden connected with the school is a very old one. Gardening was practised in some European schools many years ago, and was carried on often for the purpose of increasing the salary of the teacher or for furnishing products for him. In other schools there were botanical gardens where the specimens could be studied by the pupils. The school-garden movement as it exists to-day is of more recent origin, beginning about thirty-five years ago. The progress has been most rapid in Europe, where there are to-day more than one hundred thousand school gardens; France alone has more than twenty-eight thousand, and in Russia, as in several other countries, no school will be accepted by the state to receive state funds unless a garden is connected with it. In America, the school- 
garden movement is of recent origin, but it is gaining ground rapidly.

As sixty-five per cent. of our exports are products of the farm, it is almost alarming to think that so few of our children know anything about them. One reason why nearly ninety per cent. of the successful business men of to-day were brought up on the farm is because of the productive industry taught in early childhood in farm life. There is no kind of training that squares itself for all-round development like agriculture. The farmers' boys are brought up to use their hands as well as their heads, and learn quick observation and quick decision, which is of great value to them throughout their lives. The child's garden certainly brings his life more nearly to that of the country child than any other form of study. As an aid to nature-study there is nothing to equal it. It can be used to help in nearly every other branch of study taught in the schoolroom. The practice in measuring and marking out the 
gardens, and in systematically planting the seed, gives the child the practical mathematics which he so much needs. Much language work can be given in connection with it; in fact, it can be correlated with nearly all the other branches, as it furnishes material for writing, painting, drawing and geography. Even business can be taught, as is done at the school gardens at the State Normal School at Hyannis, Mass., where the products of the gardens are sold, the money is taken to the bank and deposited, and the children learn the method of depositing money and drawing checks. The systematic care of tools and the systematic order of doing things, and the habits of close observation and of reporting observations, acquired by the child, will form a trait which will be invaluable to him throughout life. Where gardens have been conducted for several years, long enough to make practical tests, it is found that the boys having the garden work are thirty per cent. more rapid in 
mental, moral and physical development than those not having gardens. The school garden tends to develop the best traits in the children, and to create in them a love for the beautiful. It gives play to all their motor activities, and shows that results follow causes, and is one of the best methods of curing them of stealing. They begin to understand something of ownership and responsibility, and look more kindly at their neighbor's products, and, as they do not wish to lose their own, that for which they have worked, the value of the product of another is more forcibly demonstrated to them. The school garden can be made especially valuable to girls, particularly those in the city, as they do not have the same liberties of the street as have boys, and are in the open air and sunshine all too little for good, strong physical development. 
How to Make a School Garden 



\section{CHAPTER I}

\section{How to Make a School Garden}

$\mathbf{P}$

ROBABLY no two school gardens can be made exactly the same, because of the different conditions of space and exposures and the difference in the surrounding conditions, all of which should be taken into consideration. In making the school garden, the esthetic side should not be lost sight of, nor should it be the entire controlling element; but let the esthetic and the agricultural elements harmonize. If the grounds are small and the only space for a garden is along the fence, of course there is no choice; and if this is all there is, that should be utilized: much good can be accomplished even by working in a very small space. In the absence of any available land on the 
school grounds the use of a nearby vacant lot can often be obtained.

For lower grades it probably is as well to have a general bed or garden. The conditions of every place will have to be considered; but where conditions are . favorable for the individual garden, it gives a certain amount of responsibility and interest that the general garden does not. It shows exactly what the individual is doing and helps to develop the individuality of the child. Very often, too, the excellence of several of these individual gardens will inspire those to much more careful work who naturally are inclined to be a little slack.

Where possible, it is better to grow both vegetables and flowers. This develops both the esthetic and the practical side of the pupil, and soon the child who does not love flowers, if there be such, will love the flowers that he raises, and in so loving them will be uplifted. In growing crops, grow common things. Those who have plenty of land can grow 


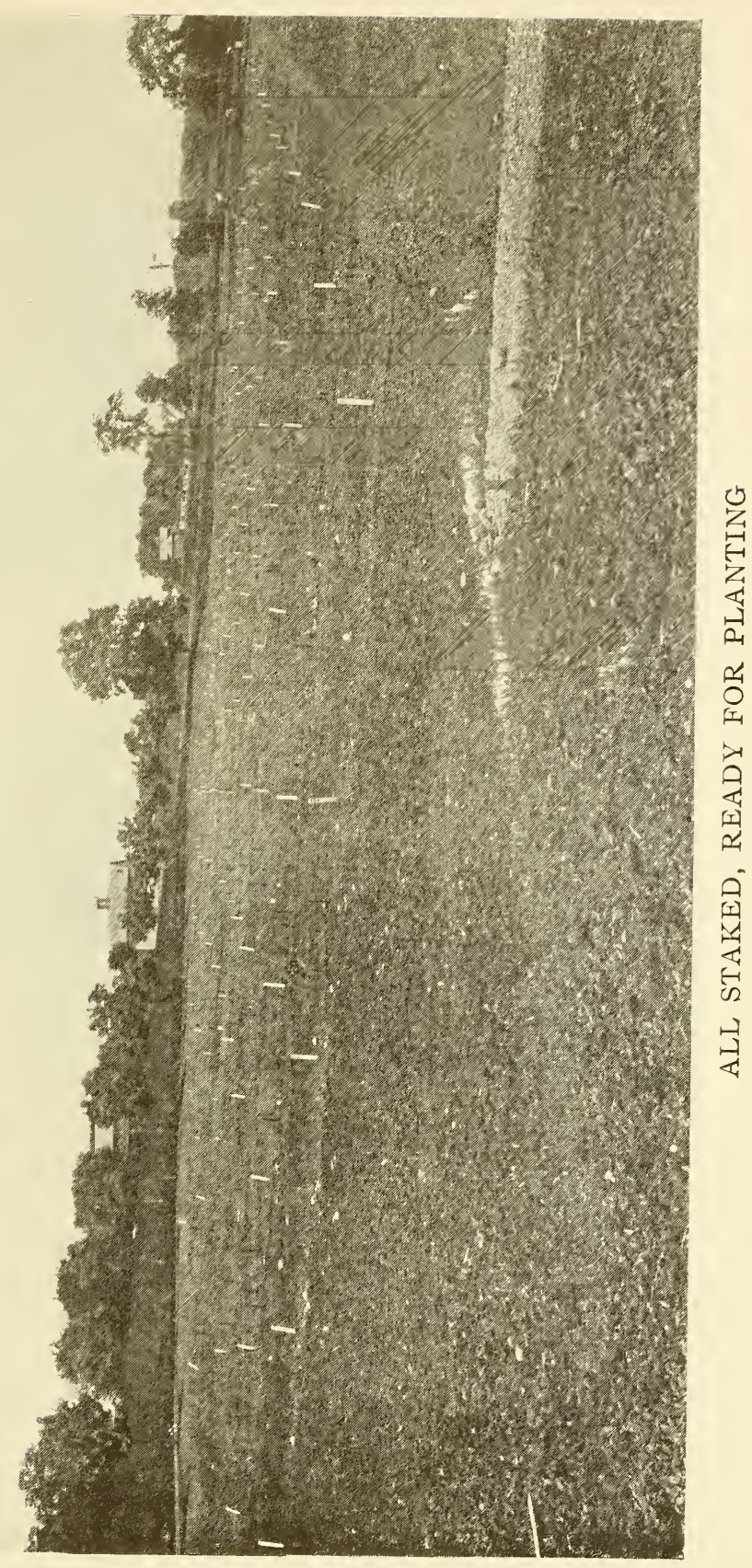



the things that are uncommon; but it is much better that the child should know the common things, the everyday things of life, the things about him, than to know what grows in Africa or China or Japan. After he knows the common things he can learn the others, if there be time and space.

If the gardens are to be individual gardens, they should be staked out with a stake at each corner, which is driven securely into the ground. One of these stakes can be numbered; or, better still, place an eighteen-inch nursery label in the front centre with the number upon it. It is easier to keep track of the pupils by number than by name, especially if there are many of them. With individual gardens, they may vary from two feet square to ten by one hundred and ninety feet, as do the various school gardens now in existence in the United States. Where the gardens are of large size, it is found easier to have them longer than wide. If these gardens are open to exposure on 
all sides, the rows should run either north and south or east and west. With the north and south method, the sun is perhaps more evenly distributed to every crop, as it goes down the rows between them as it passes in its journey. If , the rows run east and west, for success it is necessary to plant all high-growing plants on the north side, so that they will not shade the other crops. If there are to be several rows of gardens, this will not interfere with the other gardens, as the walk will be wide enough to take the shadow. Do not crowd. It is better to grow a few crops well than to try to grow many and not succeed.

It is not generally wise to use toy tools. The triangular hoe which strawberry growers use is light and will be found efficient for all purposes. Any child large enough to work in a garden can handle a ten- or twelve-tooth rake. It will be found very convenient to mark the handles of the hoes so that the pupils can measure by them. A line is almost indispensable, 
and should be long enough to go around the entire garden. This can easily be made by cutting up a ball of good twine. $\mathrm{T} h \mathrm{e}$ four-strand braided $t w$ in e is best for this purpose. A twelve-inch pot label makes a very good stake for one end, and has the advantage that it can be numbered; any strong stick can be utilized for the other end. If small crops are grown, the hand weeder will be found useful, although not essential. Where the children spade up their own gardens, the s pades should be smaller than the ordinary garden spade. These can be procured, however, from most local

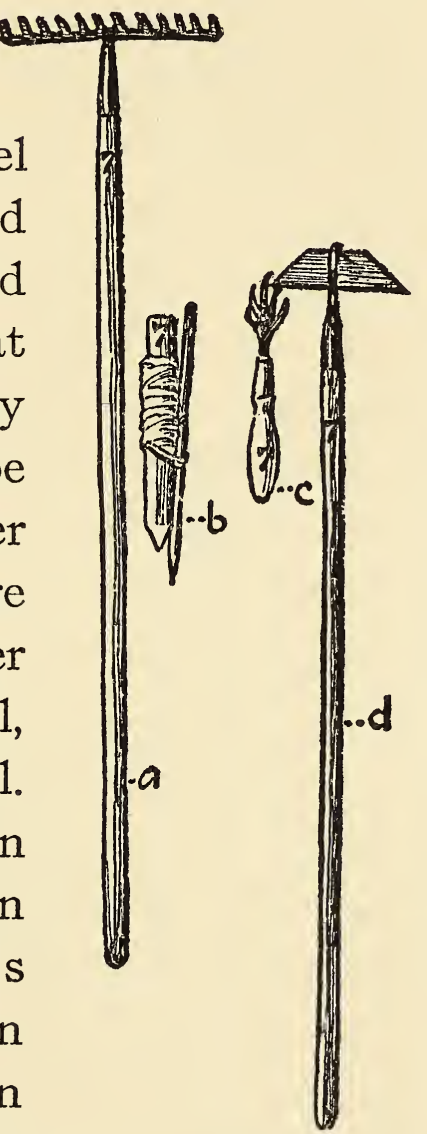

THE NEEDED TOOLS
a. Rake, 12 in.
c. Hand Weeder
d. Sunnyside Hoo 
dealers. The land should be thoroughly fertilized.

Before going with a class of pupils into the gardens to stake them out, it is well to explain what is to be done, and to illustrate if possible on a blackboard. If the children are able to lay out the gardens accurately without assistance, after it has been explained to them, they are certainly above the average. Few children are able to apply their mathematics, although they may be very bright in book-work. The walks should be so arranged that the gardens are easily reached from the entrance, where, if there is sufficient land and there are several rows, five feet is not too much for the walks between the rows of gardens, and there should be a walk of from eighteen inches to three feet between each garden. This, however, is not always feasible and can be dispensed with, but it is desirable. If the gardens are next to a fence, especially a board fence, the tall plants should be located there, regardless 


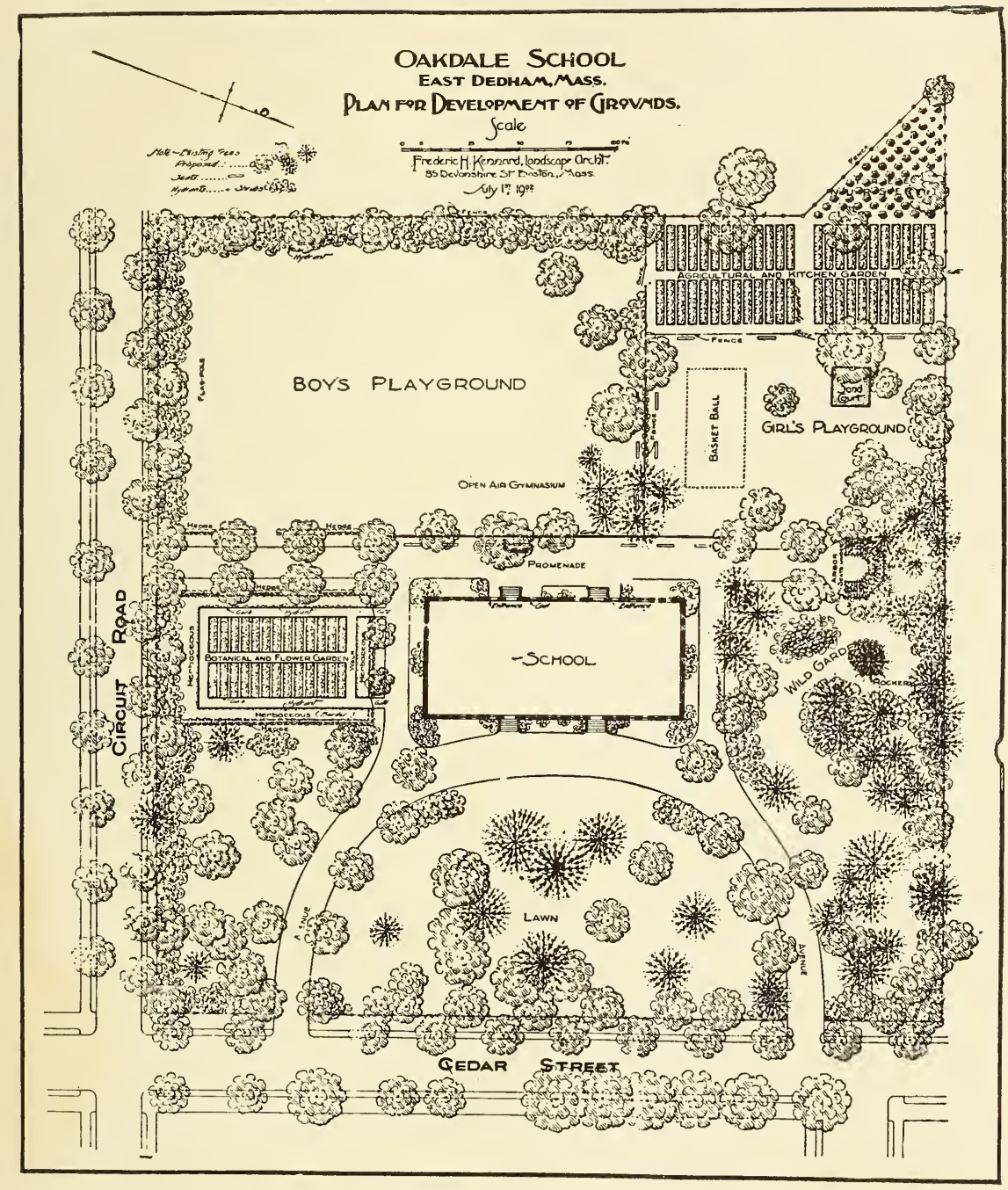



of the exposure, as the fence would shade on the one side and the tall plants on the other, if planted in any other place.

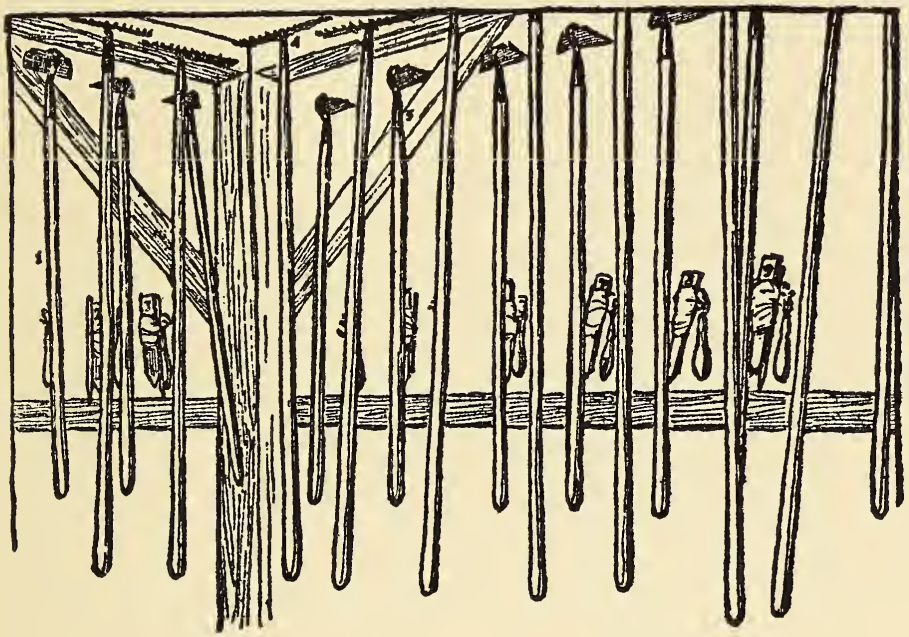

A CORNER IN THE TOOL ROOM

With individual gardens, it is well to give the children seeds put up in packages, with just enough for the row in each package. Otherwise there may be a waste. Measuring tape, stakes and a mallet or hatchet, and sometimes a line, are required for marking out the garden. Very good stakes can be made by cutting up furring strips, which can 
IO HOW TO MAKE SCHOOL GARDENS

be obtained from any lumber dealer. These are inexpensive and are strong. They should be driven into the ground at least one foot. With the garden marked out, it is time for the lessons in planting to begin. 
How to Prepare and Fertilize the Land 



\section{CHAPTER II}

How to Prepare and Fertilize the LAND

Perhaps the most serious problem, especially to the city school, after the necessary land has been obtained, is, How shall we prepare and properly fertilize it? This is a difficult question to answer, as the soil is hardly alike in any two places. While fertilizers are usually necessary on every soil to some extent, tilth is of far greater importance. Tilling the soil is to the plant what training and schooling is to the child. The child and the plant must have proper food, to be sure; but that only does not develop much of a desirable being.

If the plot of ground is large enough, it should be thoroughly plowed; and, where the subsoil is very compact, the 


\section{I4 HOW TO MAKE SCHOOL GARDENS}

plow should be followed in the same furrow with the subsoil plow. This breaks it up, makes it more porous, and allows the water to pass through. Small lots, too small to be economically plowed, should be spaded; and, where the subsoil is impervious, it can be trenched.

- If the ground is in turf it should be well turned and then thoroughly harrowed. If the land was not in turf, or if the turf is decayed after plowing, it should be replowed, running the furrows in the opposite direction. If spaded, the sod should be turned deep. It can again be lightly spaded. The aim should be to give thorough tillage to obtain all possible from the land, and then apply fertilizers to get more. Tillage sets at work the forces which unlock plant food. Fertilizers are more useful to the plant on well-tilled land.

\section{FARM MANURES}

The valuable plant food in farm manures is not so quickly available as in high-grade commercial fertilizers; but they have the 


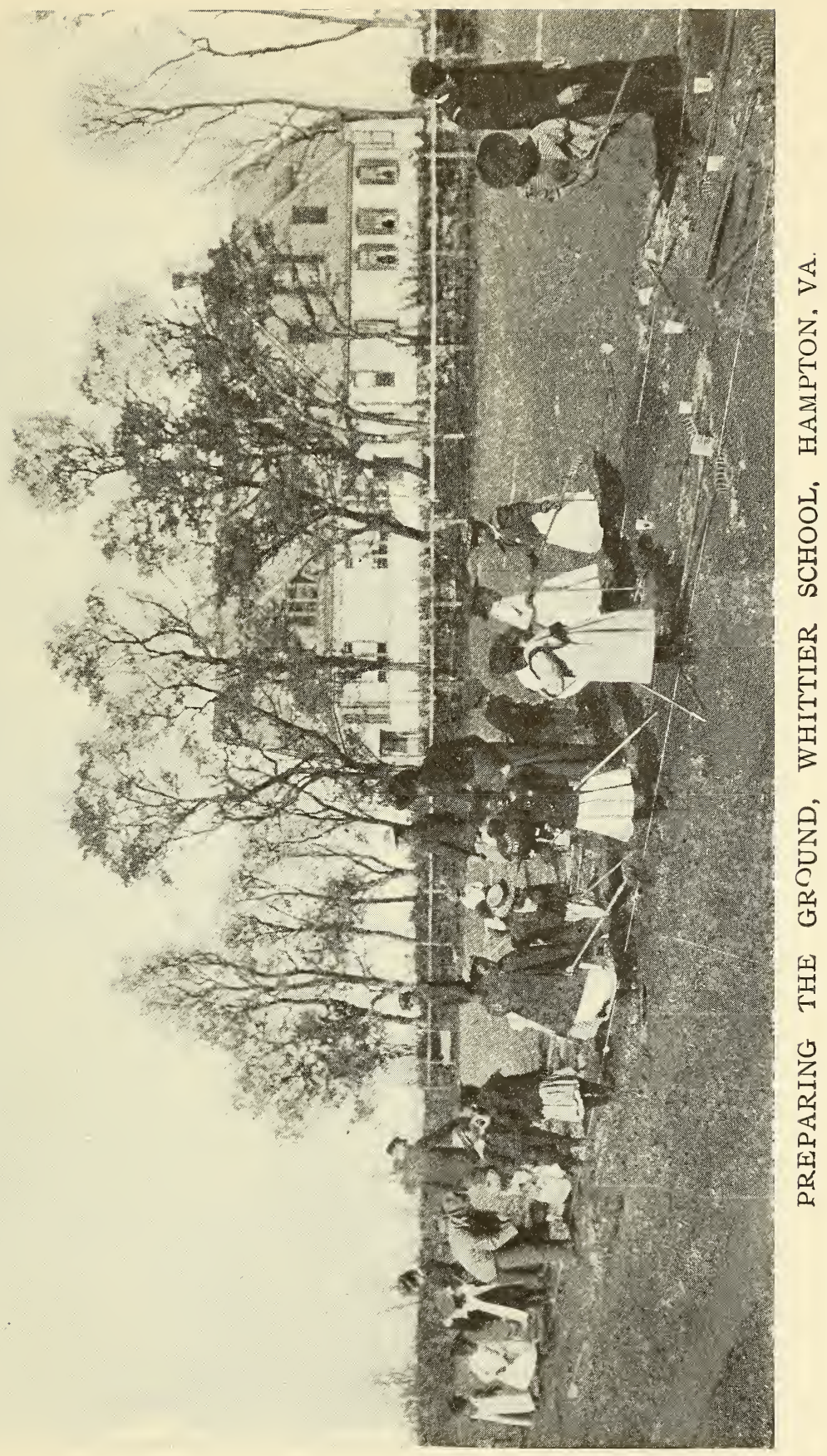



additional value of supplying humus, which lightens the soil, increasing its power to hold water. It also assists in liberating the mineral substances in the soil. If the manure is coarse, it should be rotted to increase its availability before applying. There are three elements necessary to supply to the soil: nitrogen, potash and phosphoric acid. Farm manures supply all of these, but not always in the proportion needed.

Commercial fertilizers can be bought and applied separately or in combination. It must always be remembered that they are very powerful and should never be placed in contact with roots or seeds, but should be mixed with the soil.

Nitrates stimulate the vegetable system and tend to produce dark-green foliage. The application of too much nitrogen has a tendency to make the plant "run to. leaves" at the expense of flowers and fruit. A lack of nitrogen is shown by weak growth of a yellowish-green colour. Nitrate of soda and sulfate of ammonia are 
the forms in which nitrogen is most often used. It should be applied in the proportion of 150 to 300 pounds per acre.

Potash, among other effects, stimulates the production of plump seed and fruit and intensifies the color of the bloom. A deficiency of potash is shown by a lack of fruit and small, often immature, seeds. It is best supplied as sulfate and muriate of potash and unleached wood-ashes. The latter often has a chemical effect on heavy land to some degree the same as lime. Sulfate and muriate of potash are applied 200 to 400 pounds to the acre; wood-ashes, 500 to $I, 500$ pounds to the acre.

Phosphoric acid aids in developing plump seeds. It is applied in bone compounds and fossil phosphates, as South Carolina and Florida rock. The application is from 200 to 400 pounds* of treated rock per acre. Many fertilizer dealers make what they call complete fertilizers by mixing the three required elements.

* Made available with sulfuric acid. 
If the place be small, one of these complete fertilizers would be more convenient than for one to try to mix them.

When to apply depends on the need of the plant. Plants are most benefited when they receive extra nourishment in the early stages of their growth. For this reason it is often well to give the land an application of farm manure and to apply some complete commercial fertilizer in the row. The fertilizer should, as a rule, be applied just before the crops are to be planted. It should be well harrowed into the soil. The commercial fertilizer acts as a starter, being quickly available, while the farm manure carries the crop through the season, the plant food in it being more slowly available.

Kind of fertilizers to be used depends mainly on two things, viz., the condition of the soil and the crop to be grown. Generally speaking, sandy soils respond most freely to the application of fertilizers. When possible to obtain it, it is best to 
use a farm manure, on account of the physical help to the soil in aiding it to retain moisture. An application of ten cords to the acre will cover the land one-fourth of an inch. This is a fair application, although market gardeners often use more than double that amount. A little additional commercial fertilizer in the row will be helpful on the start. Sandy soils are most likely to be deficient in nitrates, as the latter are soluble and are washed through such soils. On heavy soils also farm manures tend to lighten them. The use of lime on such soils (those which crack upon drying) increases the growth and healthfulness of plants by improving the physical condition of the soil and sets free unavailable plant food. Wood-ashes also aid in this, besides supplying the potash. The lime should be used fine, from five to ten barrels per acre. For light, spongy soils, high-grade commercial fertilizers are as good as any. If the crop to be grown is an early maturing one, commercial fertilizers are best, 
as farm manures are not early available. For medium and late maturing crops farm manures are much the best. The whole problem of manuring is a local one, and is best determined by experiment.

Water is necessary for the assimilation of food. If the plants have plenty of food and no water, it is of no value to them. Tillage aids in keeping the water supply constant by preventing the evaporation of moisture by the sun when the weather is dry and by allowing the topsoil to dry out and get air when wet.

Plants to succeed must have food and care; the most important is care, and care is largely tillage. 

Lessons in Garden Work 



\section{CHAPTER III}

\section{Lessons IN GARDEN WORK}

The lessons in this chapter are given for gardens twenty-five feet long and ten feet wide, with rows running east and west, with the exception of Lesson I, which garden runs east and west with the rows north and south. They can, however, be adapted to any size and shape. Before beginning with the children, the use of the note-books, tools, etc., should be explained to them. Note-books can be made, if a quantity is required, as cheaply as they can be bought. A notebook $8 \mathrm{I} / 2$ by $4 \frac{\mathrm{T}}{4}$ inches makes a very convenient size for the pocket. The number can be on the outside. The first page can be ruled for the month, day, attendance and weather report, and the last pages ruled for the month and day and for 
24 HOW TO MAKE SCHOOL GARDENS

the report of all the different crops. The second page should be reserved for a diagram of the garden. These lessons can be adapted to any method. 


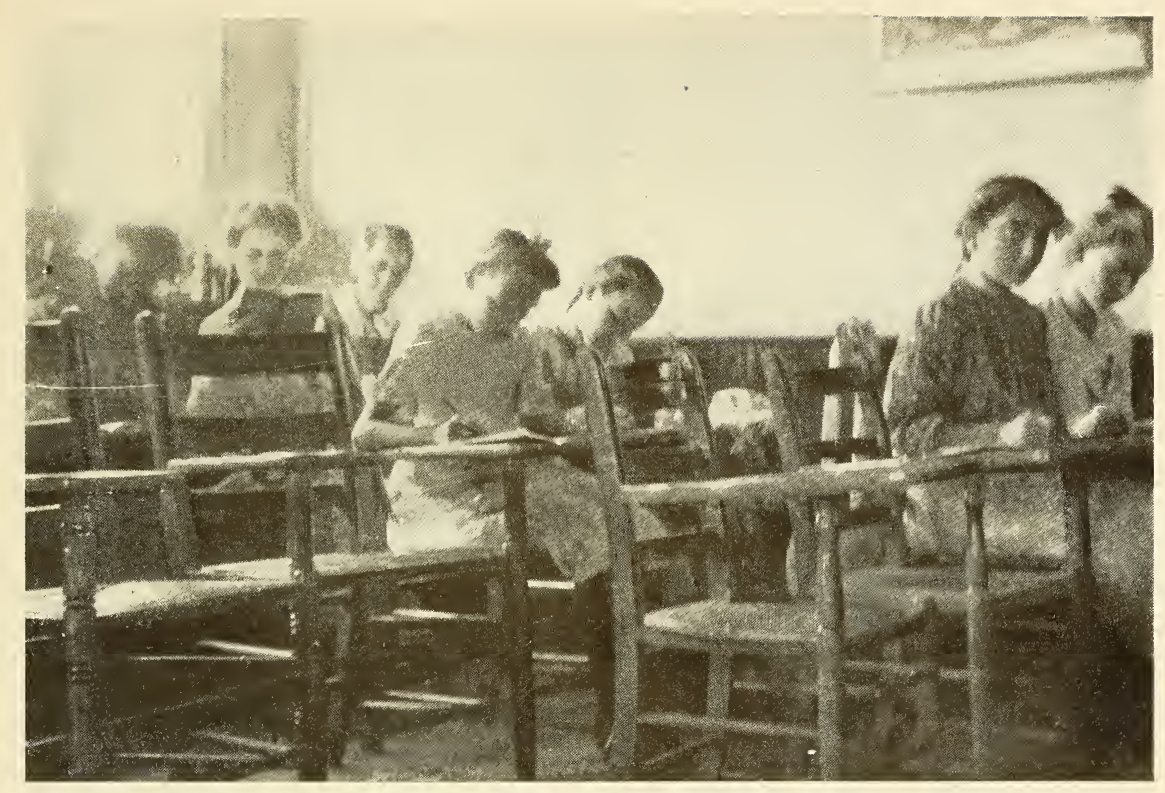

RECEIVING DIRECTIONS

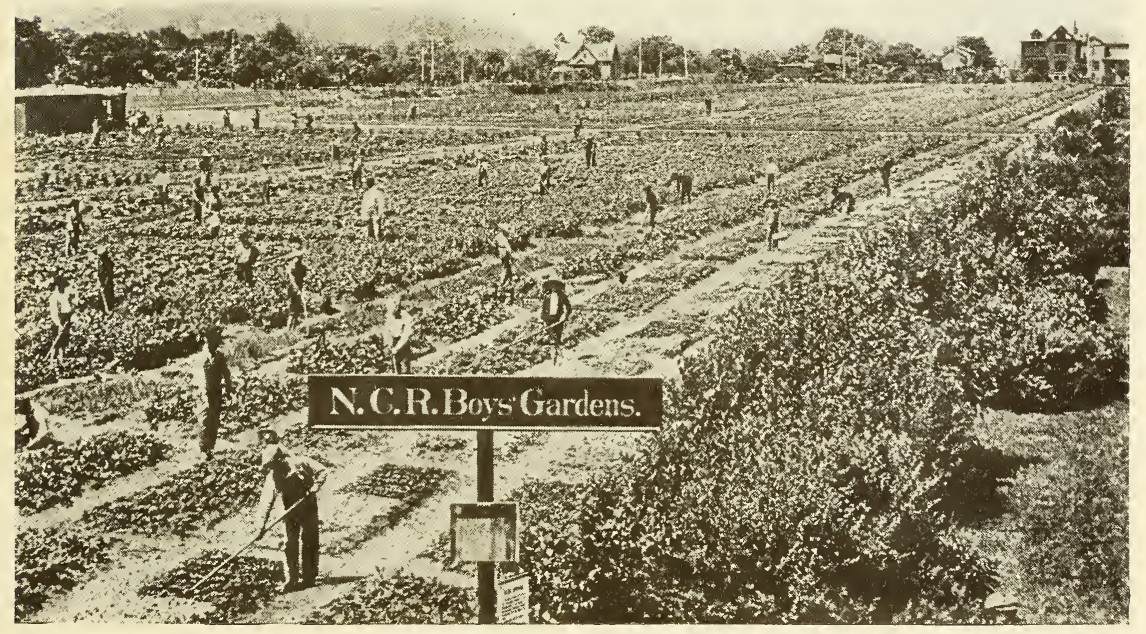

7 I GARDENS Io $x$ I 70 FEET

National Cash Register Company, Dayton, Ohio 



\section{LESSON I}

Plant one row of potatoes five feet from the west end. Dig a furrow three inches deep and plant the pieces* about one foot apart, beginning at the line. Cover at least two inches with mellow soil and pat down with the back of hoe.

Plant, two feet east of potatoes, one row of cabbage seed in hills two feet apart. Sow five or six seeds in each hill. Make the hill by loosening the soil with the hoe and removing about one inch of soil. Cover the seed one-half inch with fine soil and make it firm over the seed.

Plant, five feet from east end, one row of lettuce. Mark out the row about onehalf inch deep and sow the seed one to two inches apart. Cover with fine soil onefourth inch and press it down.

Plant, one foot east of lettuce, one row of radishes. Mark out the same as for

* The potato tubers are cut into pieces of one or two eyes each. 
26 HOW TO MAKE SCHOOL GARDENS

lettuce. Cover one-fourth inch with fine soil and press down. Use your line in marking each row. Measure with hoe handle. 


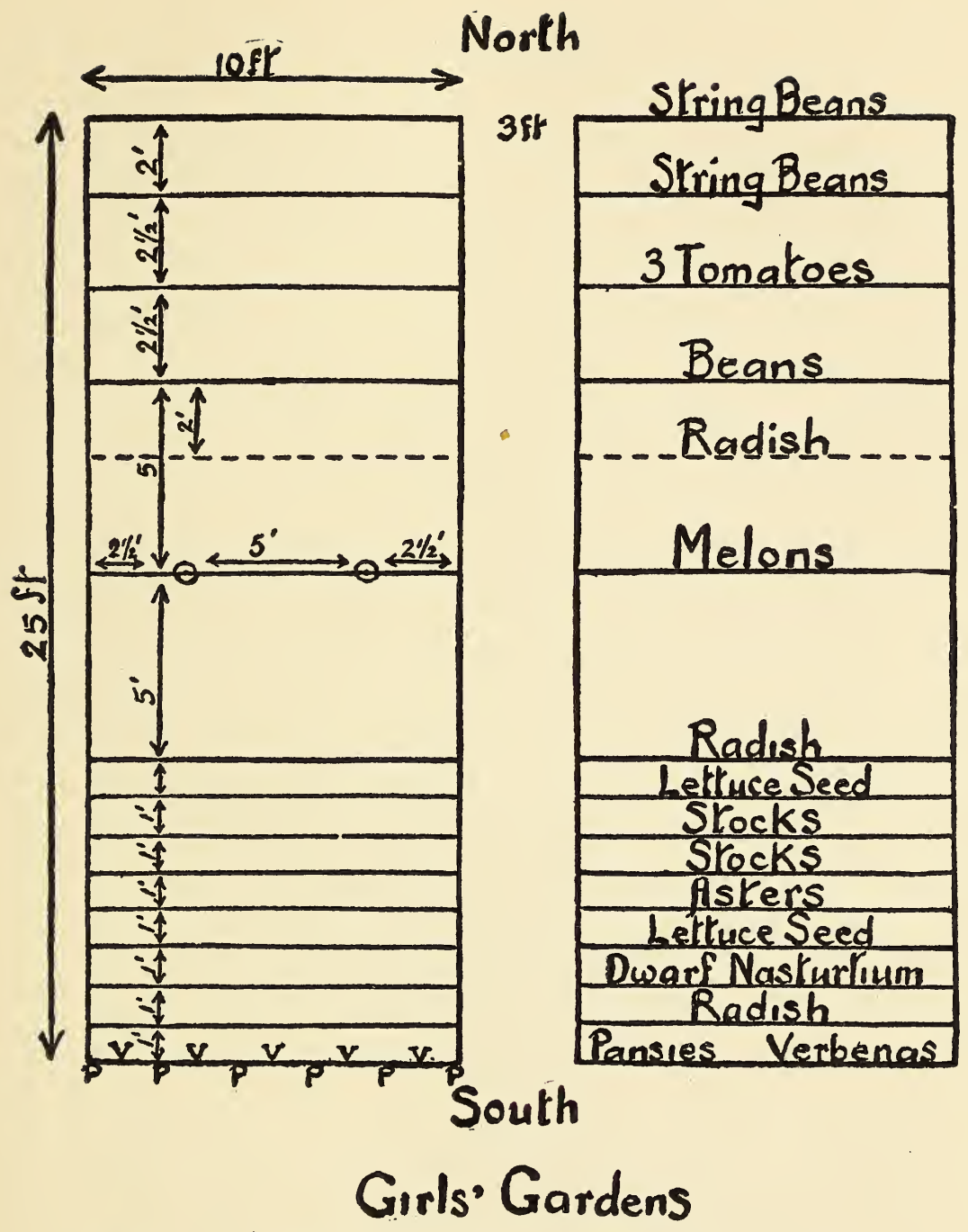

School of Horliculture, Hartford, Conn. 


\section{LESSON II}

Rake the south end of garden six feet, breaking up the lumps, leaving the surface level with the contour of the land.

Plant, three feet from south end, one row of lettuce. Measure each side carefully, run the line across and make a mark or furrow about one-half inch deep and sow the seed one to two inches apart. Cover with fine soil one-fourth inch and press down with the back of the hoe.

Plant, one foot north of lettuce (four feet from south end), one row of beets. Make a furrow or mark one inch deep and sow the seed one to two inches apart. Cover with fine soil three-fourths of an inch and make it firm over the seed.

Plant, one foot north of beets (five feet from south end), one row of radishes. Mark as for lettuce, sow the seed one inch apart and cover with fine soil onefourth to one-half inch and press down. 


\section{LESSON III}

Set out, ten feet from south end, one row of lettuce plants one foot apart. Set them in the ground the same depth that they are growing. Be careful and not disturb the roots. If the soil is hard, loosen it with the hoe and set the plants with the hands. Make a hole for the plant with the right hand, lower the plant into it with the left and press the earth firmly about the roots with both hands. Level the land with the rake before setting the lettuce plants.

Level and rake south and west walks.

Dig a hole in the north end or centre of the garden, raking the lumps into it and level off.

Be careful about measuring. 


\section{LESSON IV}

Dig a hole in the centre of north end of garden and rake into it all coarse material that will not break up, leaving the garden and walks smooth and looking well.

Plant, five feet from north end, one row of dwarf horticultural shell beans. Measure carefully, put the line across and make a furrow one and one-half inches deep. Put the beans two to three inches apart. Plant out to edges of the garden, cover with fine soil one to one and one-half inches and press down.

Plant, seven feet from north end, one row of Valentine Beans, same as the others.

Loosen the soil with the hoe or weeder between the rows already planted, if the seed is up. 


\section{LESSON V}

Plant one row of sweet corn in north end of garden on the line. Make a furrow three inches deep, sprinkle one-fourth pint of commercial fertilizer along the row and hoe it into the soil. Drop three kernels every six inches, beginning at the line. Cover with fine soil two inches and press down.

Plant, two and one-half feet from the north end, one row of corn the same as the other.

Plant, nine feet from the north end, one row of radish seed, same as in Lesson I.

Set out, eight feet from the south end, one row of tomato plants. Set one Golden Dwarf Champion two feet from the west side; three feet east of this set one Fordshooks's First; and three feet east of that set one Dwarf Champion. Set the plants one to two inches deeper than they are growing in the pot and press the loose soil 
32 HOW TO MAKE SCHOOL GARDENS

firmly about the ball of earth. Dig the hole for the plant with the hoe.

Leave the walks and gardens smooth, free from weeds and looking well. 


\section{LESSON VI}

Set out one row of pansy plants in the south end of the garden on the line. Put them two feet apart, beginning at the stake, and set them the same as lettuce in Lesson II. Between each pair of pansy plants set one verbena plant the same way. Hoe over all walks, between all rows and where nothing is planted. Pull all weeds in the rows. Leave the garden and walks smooth, free from weeds and looking well. 


\section{LESSON VII}

Plant twelve feet from the north end, and two and one-half feet from the west side of the garden, one hill of watermelon seeds.

Plant one hill of muskmelon seeds two and one-half feet from east side and twelve feet from north end. To make a hill, dig a hole one foot in diameter and four to six inches deep; fill this hole to within one inch of the top with a mixture* of equal parts of well-rotted manure, sand and soil to furnish a light soil so the plants can get a quick start. Scatter the seeds all over the hill, cover with fine soil one inch and press it down.

Plant, six feet from the south end, one row of radishes, same as lettuce in Lesson $I$.

Hoe between all rows and hoe up the weeds in the south and west walks. Pull

* In sandy soil only the manure is necessary. 
every weed in the rows and leave the gardens looking well.

Thin the lettuce to two inches apart, transplanting enough to fill out the row.

Pick flowers and pull radishes and lettuce if ready. 


\section{LESSON VIII}

Hoe between all rows and hoe over the south and west walks.

Plant, one foot from the south end, one row of Dianthus pinks. Put two or three seeds every eight inches, beginning at the line. Have the ground soft by hoeing deep.

Two feet from south end plant one row of asters eight inches apart, the same as the pinks.

Pull all weeds in the rows and leave a soil mulch over the whole garden. Use the weeder near the plants.

Pick and kill all potato beetles.

Pick all flowers and pull the radishes and lettuce that are ready. 


\section{Lesson IX}

Hoe between all rows and hoe up the weeds in the south and west walks. Pull all weeds in the rows and leave a soil mulch* over the whole garden, using the weeder near the small plants.

Set out, eleven feet from the south end, one row of lettuce plants eight inches apart. Set them the same as in Lesson II. Take the plants from the seed-lettuce row, taking out every alternate one, beginning with the second. Take them up carefully with the corner of the hoe, with soil on the roots of each.

On the north side of each tomato plant, drive down a stake about four inches from the plant and tie the plants to them carefully.

* A soil mulch is a loose condition of the top soil for an inch or two. It acts as a blanket, preventing rapid evaporation. It also tends to check the germination of weeds. It is essential to good, healthy, rapid growth. 
38 HOW TO MAKE SCHOOL GARDENS

Plant, five feet from south end, one row of radishes same as lettuce in Lesson $I$.

Sift ashes* and Paris green over the melons.

Pick flowers, and pull radishes and lettuce, if ready.

* This is prepared by mixing thoroughly one teaspoonful of Paris green with two quarts of woodashes. Just a very little is sifted over the plant. 


\section{Lesson $\mathrm{X}$}

Hoe between all rows and over the south and west walks. Pull every weed in the rows and leave a soil mulch over the whole garden.

Thin out the corn, leaving one stalk every six inches.

Thin the beets to two inches apart and take home for greens those pulled out. Sift ashes and Paris green over the melons.

Pick flowers, and pull radishes and lettuce, if ready. 


\section{LESSON XI}

Hoe between all rows and over the south and west walks. Pull every weed in the rows and leave a soil mulch over the whole garden.

Sift ashes and Paris green over the melons.

Plant, ten feet from south end, one row of Big Boston Lettuce, same as lettuce in Lesson I.

Plant, nine feet from north end, one row Hartford Bronzed Lettuce, same as in Lesson I.

Pick flowers, and pull radishes and lettuce, if ready. 


\section{LESSON XII}

Hoe between all rows and over the south and west walks. Pull every weed in the rows and leave a soil mulch over the whole garden.

Make a diagram of garden on page two.

Pick flowers, and pull radishes, beets and lettuce, if ready.

GRAINS

Grain is the term applied to the fruit of cereal plants or to the plants themselves. The fruit is a small, hard seed and is borne in spikes or ears. The grains are wheat, oats, rye, barley, buckwheat, flax and corn (maize). To preserve grains for schoolroom use it is best to pull them up when they are matured, but just as they are ready to turn yellow. Two or three stools should be bunched together, tied in several places to prevent breaking, and thoroughly dried. In this condition, if 


\section{HOW TO MAKE SCHOOL GARDENS}

kept from mice, they will keep several years.

Wheat is a grass closely related to barley and rye. It has a dense foursided spike, and grains longitudinally furrowed on one side, turgid on the other. Some varieties have awns or beards; one being planted in autumn, the other in spring. From it comes the principal breadstuff of the civilized world. A grain in weight was originally derived from a plump grain of wheat.

Wheat was introduced into China 2,700 B. C.

Oats differ from other grains in mode of flowering, having panicles instead of spikes. Used in human food and much used for horses. Often cut "in the milk" for a fodder crop. 


\section{LESSON XIII}

Hoe between all rows and over the south and west walks. Pull all weeds and leave a soil mulch over entire garden. Thin out melons, leaving only three good plants to a hill.

Re-tie tomato plants where necessary.

Pick flowers and string beans, and pull beets, lettuce and radishes, if ready.

GRAINS

Rye differs from wheat in that the ear bends down while in wheat it is erect. It is taller than wheat, has both winter and spring varieties, and comes next in nutritive value. Rye makes a black bread and is the chief breadstuff of sections of Europe. A coffee is made from its roasted grains. The straw is valuable for mats, etc.

Barley resembles both wheat and rye, but has longer awns, and it retains closely its husks. It has a wider leaf and 
a more yellowish-green color while growing. It can be grown over the widest latitude of any grain. The awns are barbed and poison persons of a delicate skin. It has two-, four- and six-rowed varieties.

Buckwheat is a dicotyledonous plant; flowers white, fruit a triangular seed used much for poultry and for buckwheat flour.

Flax is grown for both fiber and seed. The fiber comes from the stalks and is made into linens. The seed is used for poultices (flaxseed poultices), and is pressed to obtain linseed oil-the oil of paint.

Indian Corn is taller than the other grains. Flowers monœcious naked ovules enclosed in a husk. Of great value as a food for cattle. Much used as human food, as cornstarch and hominy. There are many varieties. It likes hot weather to grow. 


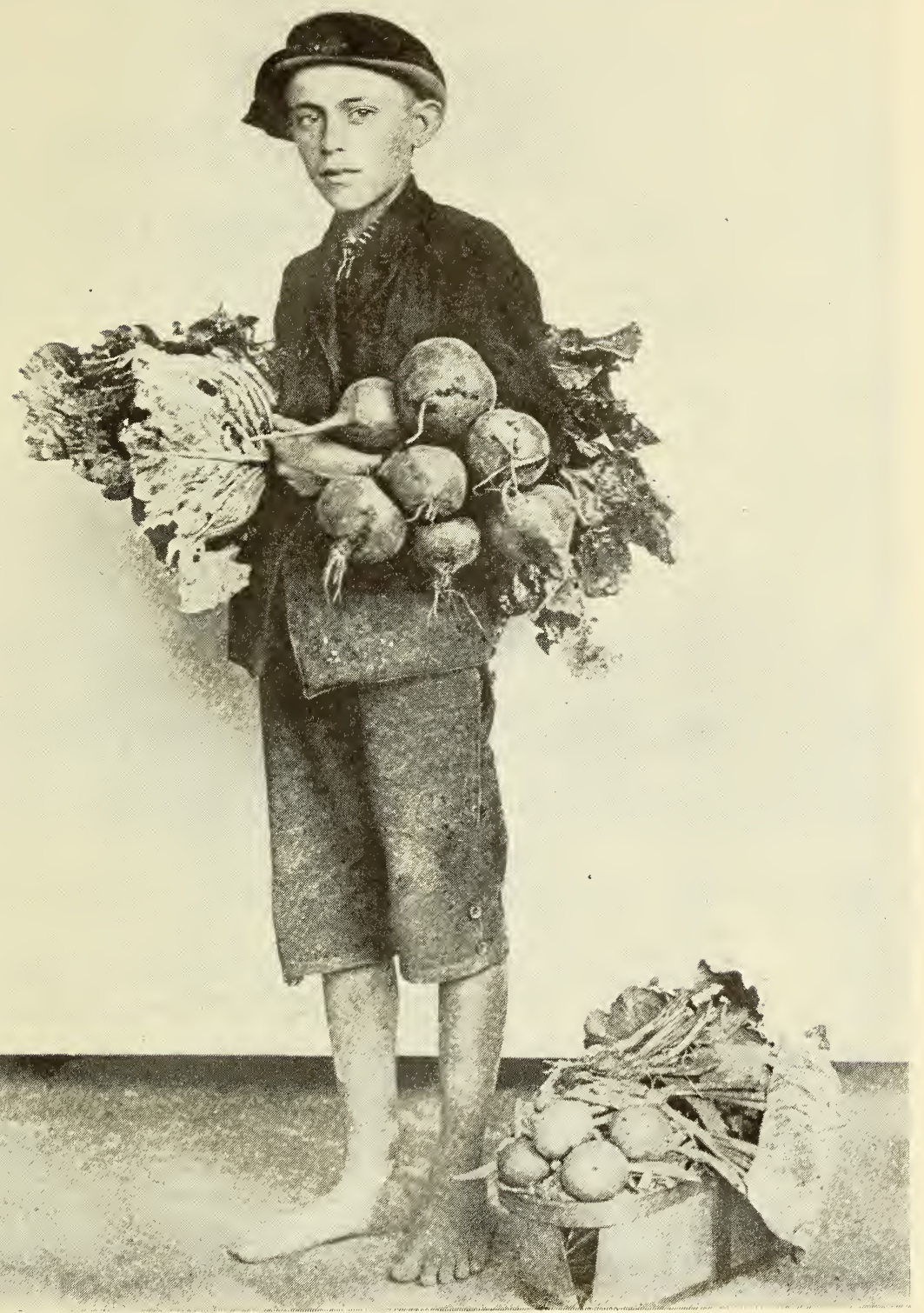

HIS OWN RAISING 



\section{LESSON XIV}

Hoe between all rows and over south and west walks. Pull all weeds.

Plant, five feet from south end, one row of beets, same as in Lesson $I$.

Thin all small lettuce to four inches apart, transplanting where necessary to fill out the row.

Pick flowers and string beans, and pull beets, lettuce and radishes, if ready.

WEEDS*

Purslane (pers'-lan), $\uparrow$ Portulaca oleracea

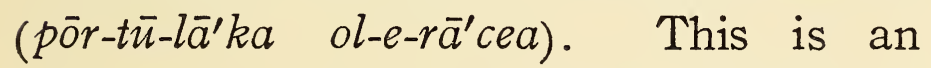
herbaceous plant, a very troublesome weed all over the United States and parts of Europe. The very fine black seed do not germinate until the weather is hot.

* It is intended that the teacher should have a good specimen of the weed in the class-room while explaining it. If possible, also have a sample of the seed in a vial. Be sure to have all parts-roots, stem, leaf, flower.

$\dagger$ Latin names should always be given so the pupil will know them when he hears them. It is not necessary for the child to learn them. 
It then grows rapidly. As the stems and leaves are so fleshy, the plant will often mature its seed even after pulled up. It easily roots at the joints. The small yellow flowers open only in sunlight and remain open but a few hours. The seed has very great vitality, being able to , remain in soil many years and then grow when an opportunity comes. The plant is used in salads, for greens (as a pot herb), in pickles and for garnishing. It is very good. It is often called pussley. Difficult to kill, it should be uprooted and removed. Best time to kill it is when it is a day or two old, by hoeing it up. 


\section{LESSON XV}

Hoe between all rows and over the south and west walks. Pull all weeds.

Plant, two and one-half feet from south end, one row of radishes, same as in Lesson I.

Cut out all corn-suckers, leaving only one stalk every six or eight inches.

Pick all flowers, string beans and tomatoes, and pull beets, radishes and lettuce, if ready.

Make out a list of what you have taken home.

Complete diagrams.

Be sure lettuce is thinned.

$$
\text { Purslane* }
$$

Smartweed $\dagger$ : Persicary, peach-wort, heartsease, smart grass, spotted knotweed, knot-grass, lady's-thumb. Polygonum Persicaria (pō-lig'-ō-num per-si-ka $\bar{a}^{\prime}$ -

$*$ Review weeds each lesson in class-room and point out same in gardens until pupils become familiar with them.

$\dagger$ Always have the weed present. 


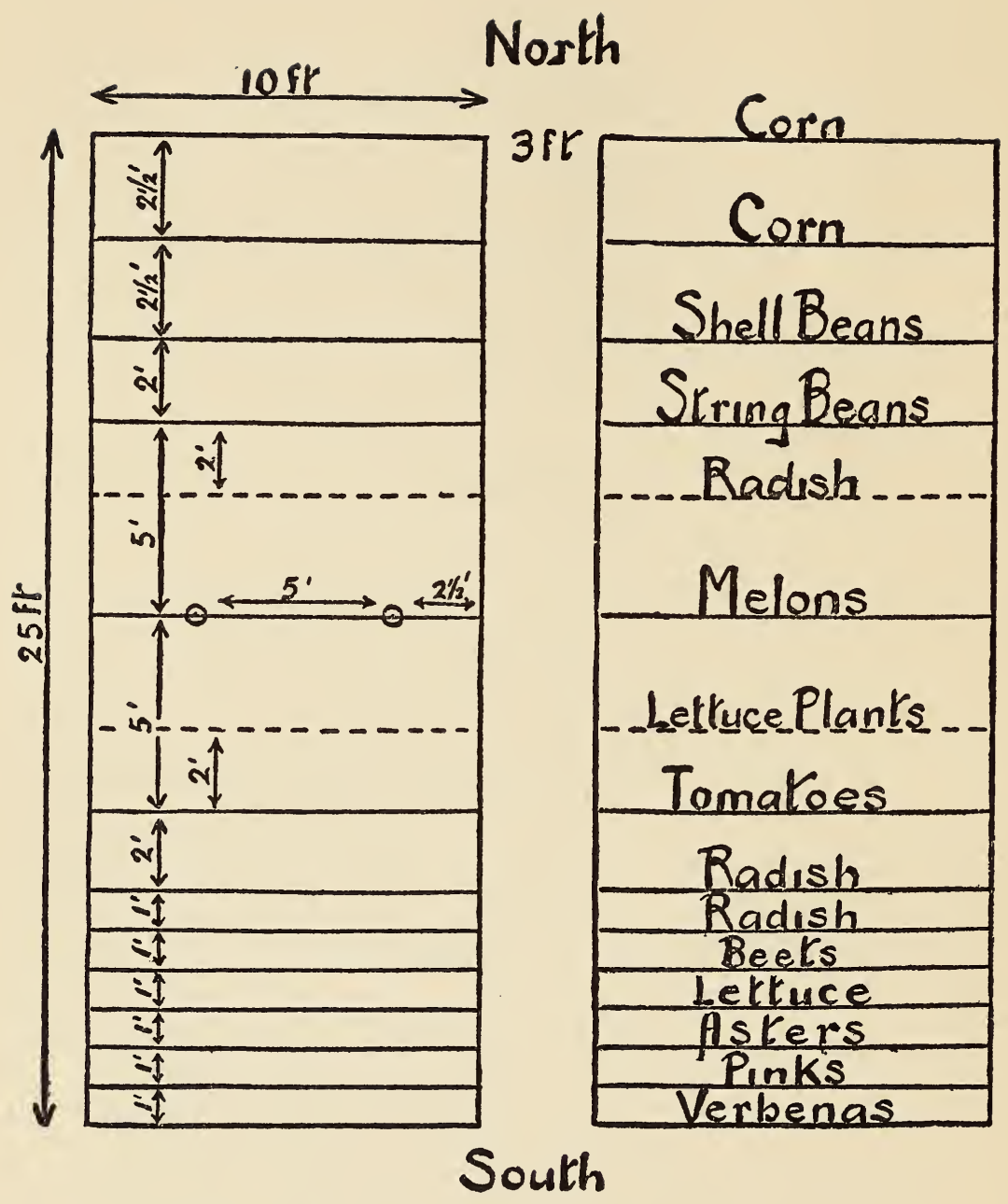

First Year. Boys'Gardens, School of Horluculture, Hartford, Conn. 
$r i-\bar{a})$. This weed grows from one to three feet high; has peach-like leaves with dark spots on them. The seed is very shiny and black. It is a very troublesome weed in the United States and parts of Europe. Grows most abundantly in damp seasons or in moist places. There are many kinds of knot-grass. This one is closely related to the Prince's-feather. Joints of stems always swollen. Flowers white or pink. The weed is used in medicine.

Killed only by pulling up, as it will sucker if broken off. Best time to kill it in the garden is when it is very young. 


\section{LESSON XVI}

Hoe between all rows and over the south and west walks. Pull all weeds.

Plant, three and one-half feet from south end, one row of radish seed.

Pick flowers, string beans and tomatoes, and pull all beets, radishes and lettuce that are ready.

Ragweed*: Roman wormwood, hogweed, bitterweed: Ambrosia Artemisiae-

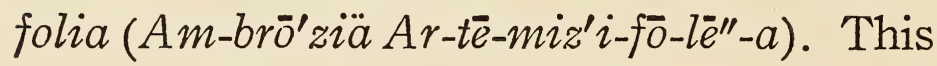
ragweed is a very troublesome weed. It grows along roadsides and in waste places everywhere. Its height is one to four feet. Much branched; leaves vary, generally much divided or compound. The juice is bitter. The flowers are greenish, with stamens and pistils in different flowers on the same plant.

The pollen from this weed is said to cause hay fever, so some persons have to

* Always have the weed present. 
go to the mountains or places where it does not grow during its blossoming period. It produces a very peculiar irritating odor. Killed by pulling up or breaking off. Best time to kill it is when very young. 


\section{Lesson XVII}

Pull all weeds. Pick string and shell beans, if ready, and pull up the vines. Pull all the beets.

Set out one row of Hartford Bronzed Head Lettuce plants seven feet from north end, and one row Big Boston Lettuce plants four feet from south end, setting the plants one foot apart. Take lettuce plants from rows in the garden, taking alternate plants.

Plant, five feet from north end, one row of radish seed.

Pick flowers and tomatoes, and pull radishes and lettuce, if ready.

Pigweed*: Lamb's quarters, baconweed. Chenopodium Album ( $k \bar{e}-n \bar{o}-p \bar{o}^{\prime}$ dium $a l^{\prime}$ bum). This is one of the commonest of weeds, growing two to seven feet high. Stems nearly white or mealy, also the under surface of the leaves sometimes varies some

*Always have the weed present. 
according to place where it grows. Sometimes used as a pot herb (for greens). Pigs are fond of it. Easily killed by pulling up. Best time to kill it is when very young. 


\section{LESSON XVIII}

Hoe between all rows and over the south and west walks. Pull all weeds.

Pick flowers and tomatoes, if ready.

Rough Pigweed*: Green Amaranth, pigweed. Amarantus retroflexus (Am-aran'tus rét'tro-fleks-us). This is a very common weed in cultivated land. Notice the hairy stems. It grows from one to five feet high and has a large thick panicle of small green flowers. It belongs to same family as the cockscomb and the thick Prince's-feather. It is a troublesome weed. Best time to kill it is by cultivation when very young.

* Always have the weed present. 


\section{LESSON XIX}

Pull all weeds and leave a soil mulch over the whole garden.

Thin beets to three inches apart, transplanting where necessary to fill out the row.

Turn melon vines into garden and pinch off the ends.

Plant one row of radish seed six feet from the north end.

Clean south and west walks and pick flowers, lettuce and tomatoes that are ready.

Wild Carrot*: Queen's lace handkerchief. Daucus Carota (dau'-kus ka-ro'ta). This beautiful flowering weed is so troublesome that in some places there is a law requiring it to be cut to prevent its going to seed. From this plant our common carrot has developed by cultivation. It flower.

* Always have the weed present, roots, stem and 
56 HOW TO MAKE SCHOOL GARDENS

has some medical properties. The only way to kill it is to pull it up. Best done after a rain, when the ground is moist. Never allow it to seed. 


\section{LESSON XX}

Pull all weeds and leave a soil mulch over the entire garden.

Run the line across one foot south of the garden and trim off the verbenas with the turf cutter.

Have tomatoes tied and south and west walks free from weeds.

Pick flowers, tomatoes and lettuce, if ready.

Be sure garden and diagrams are complete.

Plantin*: Common plantin, hen plant, broad-leaved plantin. Plantago Major

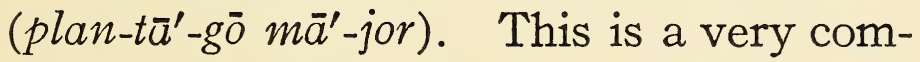
mon dooryard weed all over the United States and Europe. It does not die in winter, but the root lives year after year. The ribbed leaves, when bound on inflamed surfaces, have a soothing effect.

* Always have the weed present. 
$5^{8}$ HOW TO MAKE SCHOOL GARDENS

The stem is channeled on the upper surface. The flowers form a greenish spike: Best killed by pulling up or cutting off below the surface of the soil. 


\section{LESSON XXI}

Pull all weeds and leave a soil mulch over the garden. Have south and west walks free from weeds and looking well.

Pick flowers, tomatoes, radishes and lettuce, if ready.

Pick a little corn, leaving the largest ears. Make record of produce taken home.

FOR THE EXHIBIT

Pull a bunch of the best six beets and best six radishes. Wash thoroughly and tie neatly:

Cut and wash very carefully the best head of Big Boston and Hartford Bronzed Head Lettuce.

Pick the best six tomatoes, the best watermelon and muskmelon and best two or three ears of corn. Pull the husks down on the corn to show the ear.

Pick flowers and arrange them in 
60 HOW TO MAKE SCHOOL GARDENS

tumblers, which you must bring from home.

Arrange these things on the table in sets-vegetables, fruit, flowers.

Narrow Leaved Plantin*: Hen plant, rib-grass, ripple-grass, English plantin: Plantago Lanceolata (plan-tā'-go lan-se$\left.o-l \bar{a}^{\prime} t a\right)$. This weed is much like the broadleaved plantin, with narrower leaves, and the flowers grow on longer stems. It is mostly hairy. It is killed the same as the other one.

* Always have the weed present. 


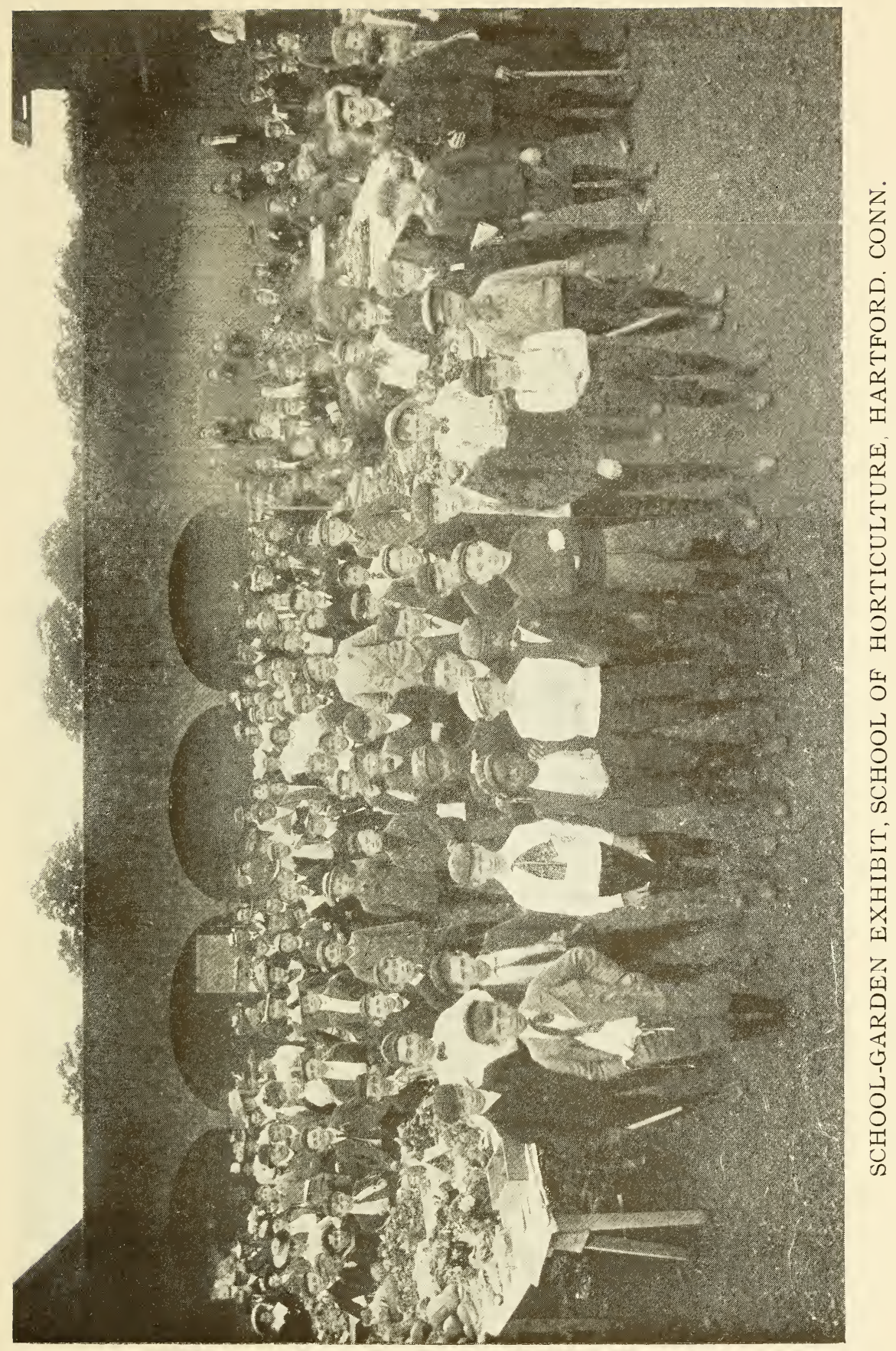



Lessons in Greenhouse Work 



\section{CHAPTER IV}

Lessons in Greenhouse Work, Planting the Seed, Potting, Shifting and Taking Cuttings.

While it is not possible, and perhaps not feasible, for many schools to have a greenhouse connected with them, it is possible to do all of the things given in this chapter right in the ordinary school-room. The windowbox or the window $\mathrm{g}$ arde $\mathrm{n}$ is the teacher's greenhouse. It may not be as convenient, but it may be of more value to the child. Children who have everything at their command in schools are likely to be discouraged when

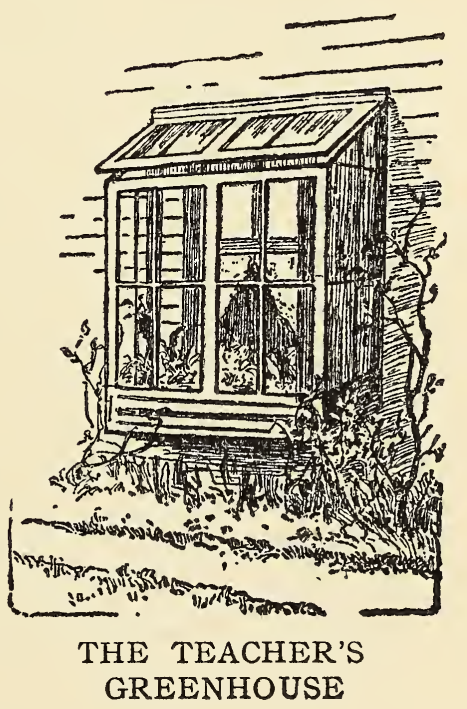


they attempt to do things at home, because they have not the things which they consider absolutely necessary. Several of the greenhouse architects now have on the market a very fine window garden which can be easily put on any window. It might be well to take up one or two lessons with the study of the seed before beginning the following lessons. The

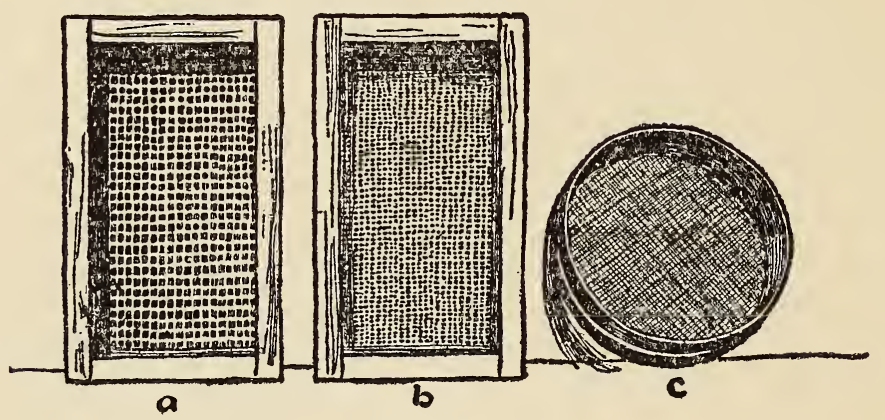

A SET OF SIEVES
a. $\frac{1}{2}$-inch mesh
b. $t$-inch mesh
c. Flour sieve

sieves used can be easily made from onehalf-inch mesh wire netting. A convenient size is twelve by twenty inches and four inches deep. For Lesson II the onequarter-inch wire mesh should be used.

The flour sieve, for covering seed, can be obtained from local dealers. 


\section{LESSON I}

For Planting Seed: Take one part of soil, two parts of sand. Mix well and sift. Put the lumps in the bottom of the shallow box, which is called a flat. Fill it nearly one-half full of lumps or broken pots for drainage. Then fill the flat with the fine soil and sow the seed rather thinly broadcast, one seed to every one-half inch of space. Cover about one-eighth inch by sifting soil on through a flour sieve. Press down evenly and firmly with a block or board. Mark the kind of seed and date on a label and place it in one corner of the flat. Take the flat to the greenhouse walk and sprinkle very carefully till wet, then place on the heating-pipes under the bench.* Coarse seeds should be pressed into the soil before covering.

* These, when treated thus, must be watched very carefully, and brought to light just as soon as the seed begins to germinate. 


\section{LESSON II}

For Planting Fine Seed: Take one part soil, two parts sand. Mix well and sift with a one-quarter-inch mesh sieve. Put the lumps in the bottom of the flat or seed pan, filling it about one-half full of lumps or broken pots for drainage. Then fill it with fine soil, scraping off the top level. Sow the seed carefully over the surface as evenly as possible. Press the soil down firmly (not hard) without covering the seed. Place the flat or seed pan into a larger water-tight box, filling the latter with water. Let the seed stand in the water until the soil is wet through from beneath. Remove it and place on the heating-pipes or in a warm place. When dry, water from beneath as at first until seeds are well up. This method is used for all fine seeds, as tobacco, petunia, Antirrhinums (snap dragons) and the like. 


\section{LESSON III}

To Pot Seedlings: Mix one part soil, one part sand, one part well-rotted manure, and sift. Use one-and-one-half- to twoand-one-fourth-inch pots. Have them clean and dip in water* before using. Place a piece of broken pot in the bottom of the pot for drainage. Fill the pot one-third full of soil, then take the plant, hold it with the left hand in the centre of pot and fill in soil evenly on all sides. Press the soil down firmly, leaving it one-fourth to one-half inch below the top of the pot. Place pots in a flat, water, and put in partial shade for a day or two. Mark the kind of plant on a label and place in one pot of each flat. To lift the plants, place the trowel or stick straight down beside the edge of the flat till below the roots,

* As pots are porous, if they are not wet they will absorb water from the soil that the roots should have. With new pots this may mean the difference between success and failure. 
68 HOW TO MAKE SCHOOL GARDENS

then press the handle down, lifting the plants. Shake off the soil carefully and pot or "prick out" a trifle lower than they grew. 


\section{LESSON IV}

To Shift or Repot: Mix two quarts of sand, four quarts of soil, four quarts of well-rotted manure, sift and add onehalf pint of fine ground bone and mix thoroughly. The pots are prepared the same as for potting, by wetting and placing drainage in them. The plant is removed from the pot by inverting it and rapping the rim of the pot lightly upon the edge of the bench. Crumble a little earth from the upper edge, remove the drainage, and crumble away the lower edge slightly. Put in enough soil over the drainage to bring the "ball of earth" about three-fourths of an inch below the top of the pot. Place the plant in the centre of the pot and fill in soil around the ball of earth, pressing firmly about the edges. Fill the pot to one-half inch below the top, press firmly, and rap lightly on the bench to 
70 HOW TO MAKE SCHOOL GARDENS

settle the soil. Water, and place in partial shade for a day or two. Never fill in soil above the first leaves of the plant. Use pots about one inch larger than those from which the plants are removed. 


\section{LESSON V}

To Prick Out Seedlings: Mix the soil the same as for potting (Lesson III). Put the lumps in the bottom of the flat and fill it the same as for sowing seed (Lesson I). Begin at the left-hand corner farthest from you. With a finger or a dibble make a hole and lower the plant into it, pressing the soil firmly about the roots. Put the plants two inches apart each way and the outside rows close to the edge of the flat. Keep the rows straight and put the same number in each flat. Mark the kind of plant on a label and place one in each flat. 


\section{LESSON VI}

To Take Soft Wood Cuttings*: Select the younger growth of the plants where the shoots are pretty well matured so that they are not too soft. They should break straight off when bent in the shape of the letter "U." If they bend only, they are likely to be too soft. If they split, they are too hard. The tops of the shoots generally make the best cuttings. Cut them two or three inches long. Then trim off the side leaves and, if the top leaves are large, cut them in two so that they will not evaporate too much moisture. They should then be inserted in clean, sharp sand at least half their length and wet thoroughly. For the school room or home, a deep plate or a shallow dish containing about two inches of sand can be used, and, after the cuttings are in, it should be placed upon a radiator. The * Coleus, geraniums and such plants. 
sand should be kept moist, and the sun should not strike the cuttings too strongly, although they should have a strong light.

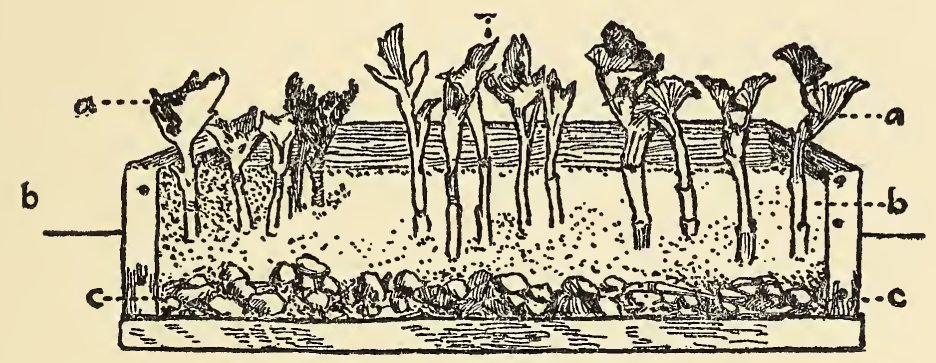

A FLAT OF CUTTINGS

a. Cuttings

b. Sharp sand

c. Gravel for drainage

They will need air. It is better to have the sand warmer than the air. The cut at the bottom of the cuttings should be made with a clean sharp knife, and should be made just below a node. 

Root-Grafting 



\section{CHAPTER V}

\section{R O O T - G R A F T I NG}

For root-grafting it is only necessary to have a sharp knife, apple or pear seedlings and the scions. It is fine handicraft work, and can be done anywhere, in the schoolroom or at any convenient place. The seedlings can be purchased of any nurseryman for from six to fifteen dollars per thousand, and the scions will be inexpensive. One seedling will make from one to six root grafts. The graftingcloth is perhaps the best thing to use for tying up the seedlings. It should be cut in strips about three-eighths of an inch wide for tying in the grafts. Any part of the root over three-sixteenths of an inch in thickness can be utilized in root-grafting. It is better to be six inches long, although not necessary. It is well to have the scions four to six inches in length. The 
78 HOW TO MAKE SCHOOL GARDENS

roots should be thoroughly washed before beginning to graft, to remove all grit. Shoe knives of good quality make excellent knives for this work and are inexpensive.

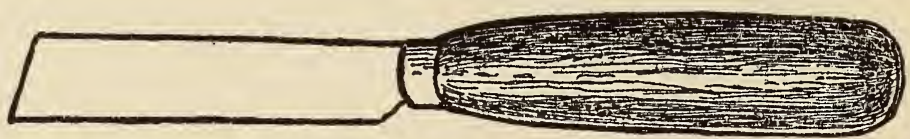

AN ECONOMICAL KNIFE FOR ROOT-GRAFTING 


\section{LESSON I}

For Grafting-Cloth: Melt four parts of unbleached resin and one part of beef tallow over a slow fire. Spread this evenly over cotton cloth with a brush or stick. Tack the cloth to a board or box, which should be warm. When cool, roll up and keep in a cool moist place until needed.

For Scions: Cut the ends of branches or twigs of desired varieties. Cut off only wood of the previous summer's growth. Label carefully and place (lying flat) in sand or moss and store in a cool moist place. Scions can be cut any time, when not frozen, after the leaves fall in autumn until the first of April.

For Grafting-Wax: Melt together four parts of unbleached resin, two parts of beeswax and one part of beef tallow over a slow fire. When thoroughly melted, cool slightly and pour into cold water. Work 
80 HOW TO MAKE SCHOOL GARDENS

with the hands (as molasses candy) until it is of a buff color, then roll in sticks and wrap in oiled paper. It can be kept in a cool moist place indefinitely. 


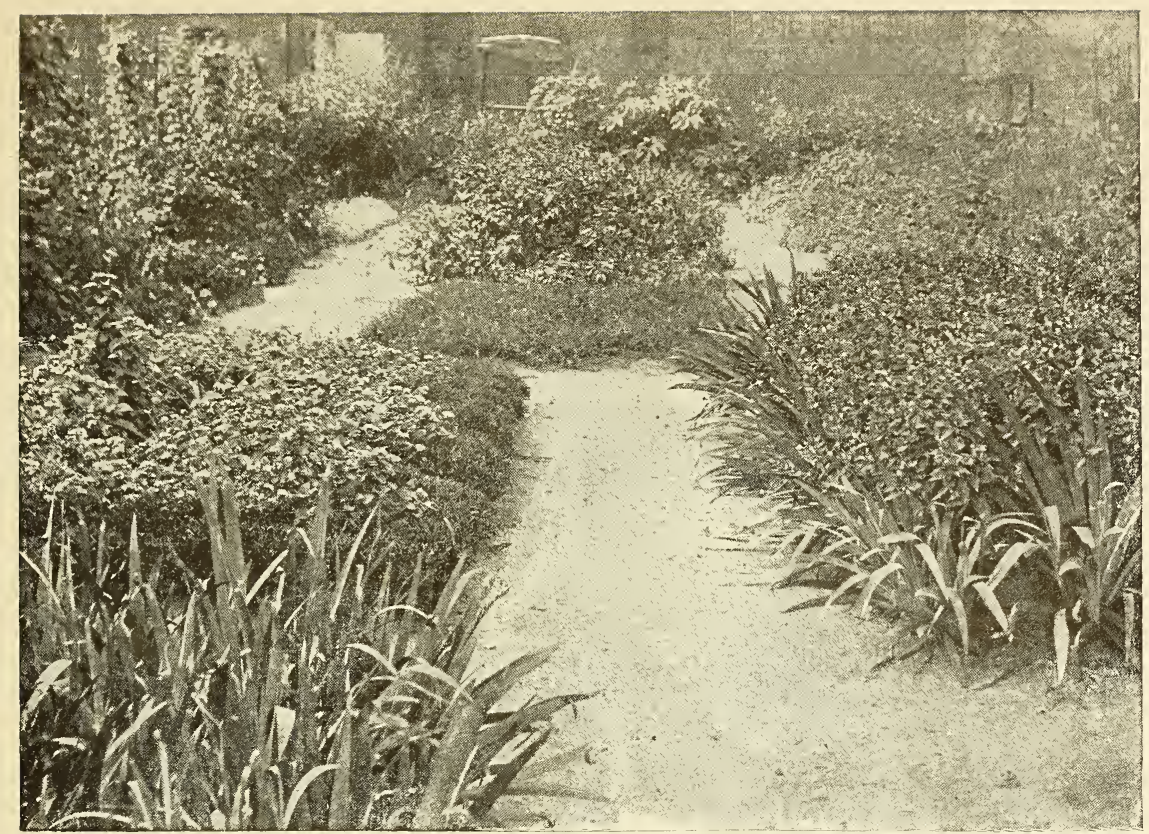

A SCHOOL GARDEN

In the business centre of Cleveland-Rockwell School

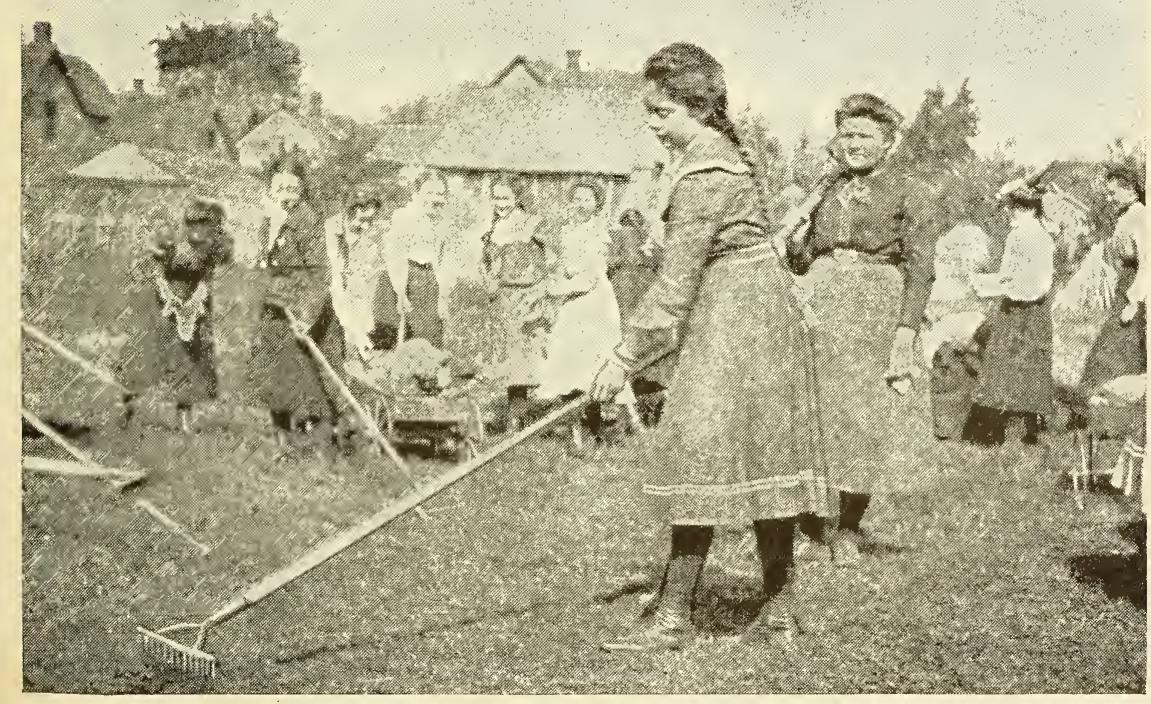

THE FUN OF MAKING A GARDEN

"The children tackled the soil with such weapons as they could muster" 



\section{LESSON II}

For Tongue-Grafting: Take the seedling roots, which are called stocks, and the scions from the boxes of moss or sand and wash them. With a sharp knife or pruning-shears remove all the root branches which are threesixteenths of an inch in diameter or more. Each piece will make a root graft. Make a long, clean, slanting cut on the upper end of each root and select a scion of about the same size and make a similar cut on the lower end of it. Cut scions about four to six inches long. See that the slanting cuts on the scion and stock are clean, smooth and match each other. Cut a little tongue in each by cutting out a small wedge-shaped chip. Press the stock and scion together firmly so that the tongues dovetail together. If they do not fit well, take them apart and try again. Be sure the inner barks of roots 
82 HOW TO MAKE SCHOOL GARDENS

and scions coincide. If the scion is smaller than the stock, carry it to one
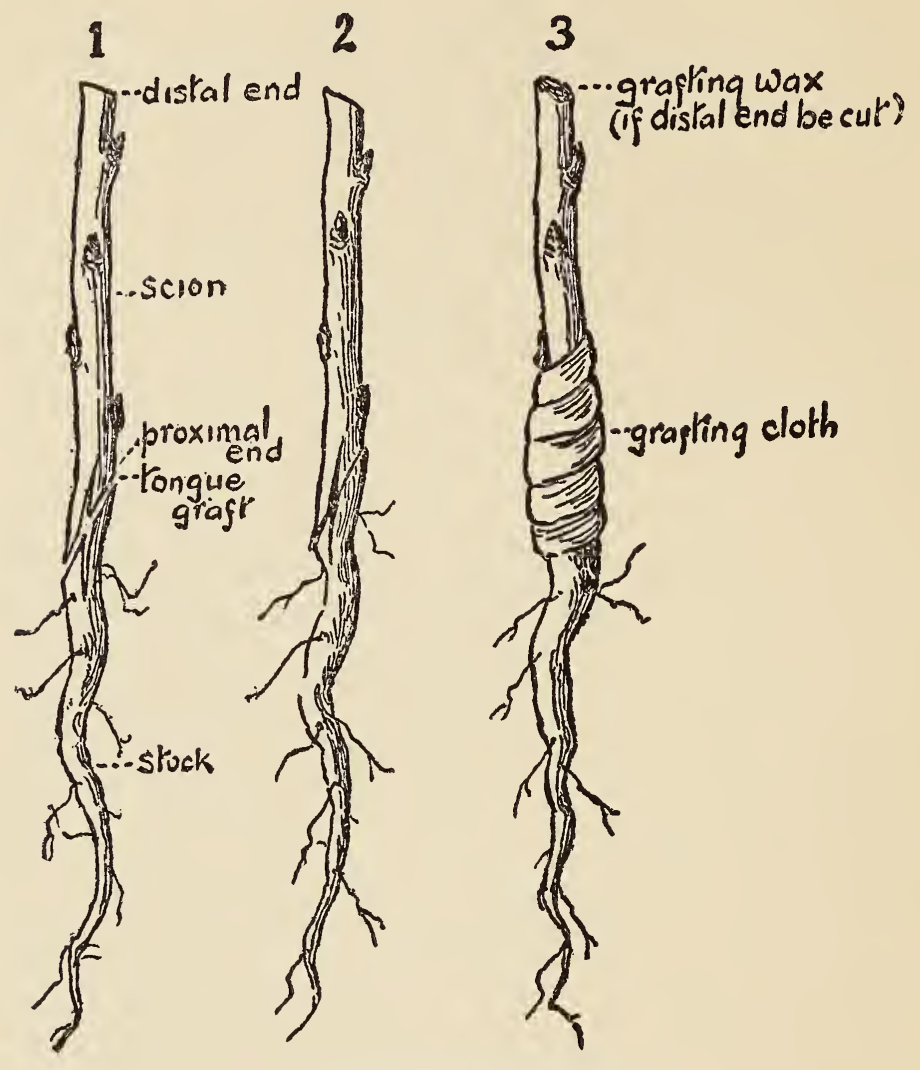

TONGUE-GRAFTING

edge so the inner barks come together. Bind firmly with warm grafting-cloth cut into strips about three-eighths of an inch wide and three to five inches long. Begin 
below the union and wind spirally till above the cut. If the distal end (top end) of the scion is cut, cover it with a little grafting-wax. Tie in bundles, marking the kind which is the same as the scions. Pack in damp moss or sand and store in a cool moist place till spring. 


\section{LESSON III}

For Saddle Grafting: Make a clean cut about one-half inch long on each side of

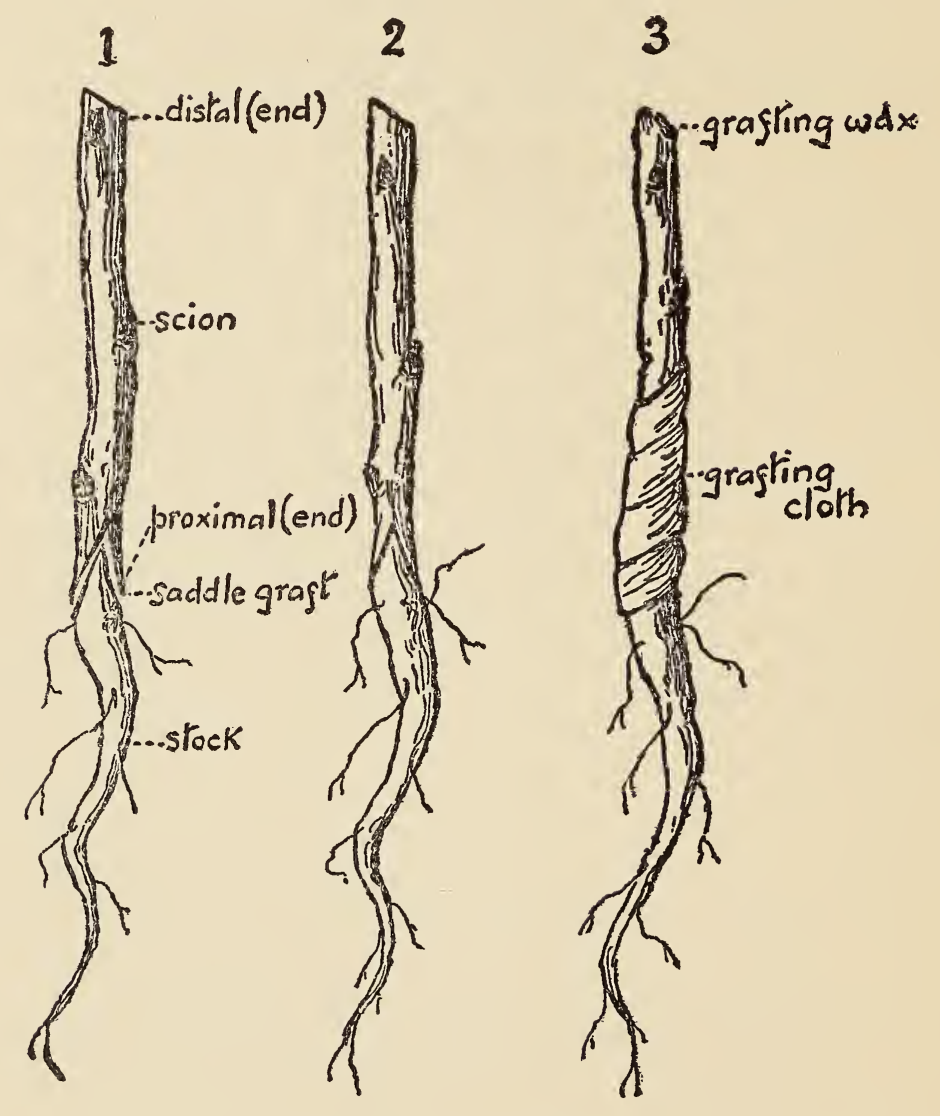

SADDLE GRAFTING

84 
the stock; then make a corresponding $\mathrm{V}$-shaped cut in the scion so that they match. If the two do not match perfectly, try until they do. Have the scion about four inches long and place it on the stock so the cambium layers of stock and scion coincide. Bind firmly with warm grafting-cloth about three-eighths of an inch wide, winding spirally from below up over the union. Store in damp moss or sand in a cool moist place till spring. Cover distal end of scion with graftingwax, if cut. 


\section{LESSON IV}

For Plain Whip-Grafting: Make long slanting cuts on the proximal end of scion

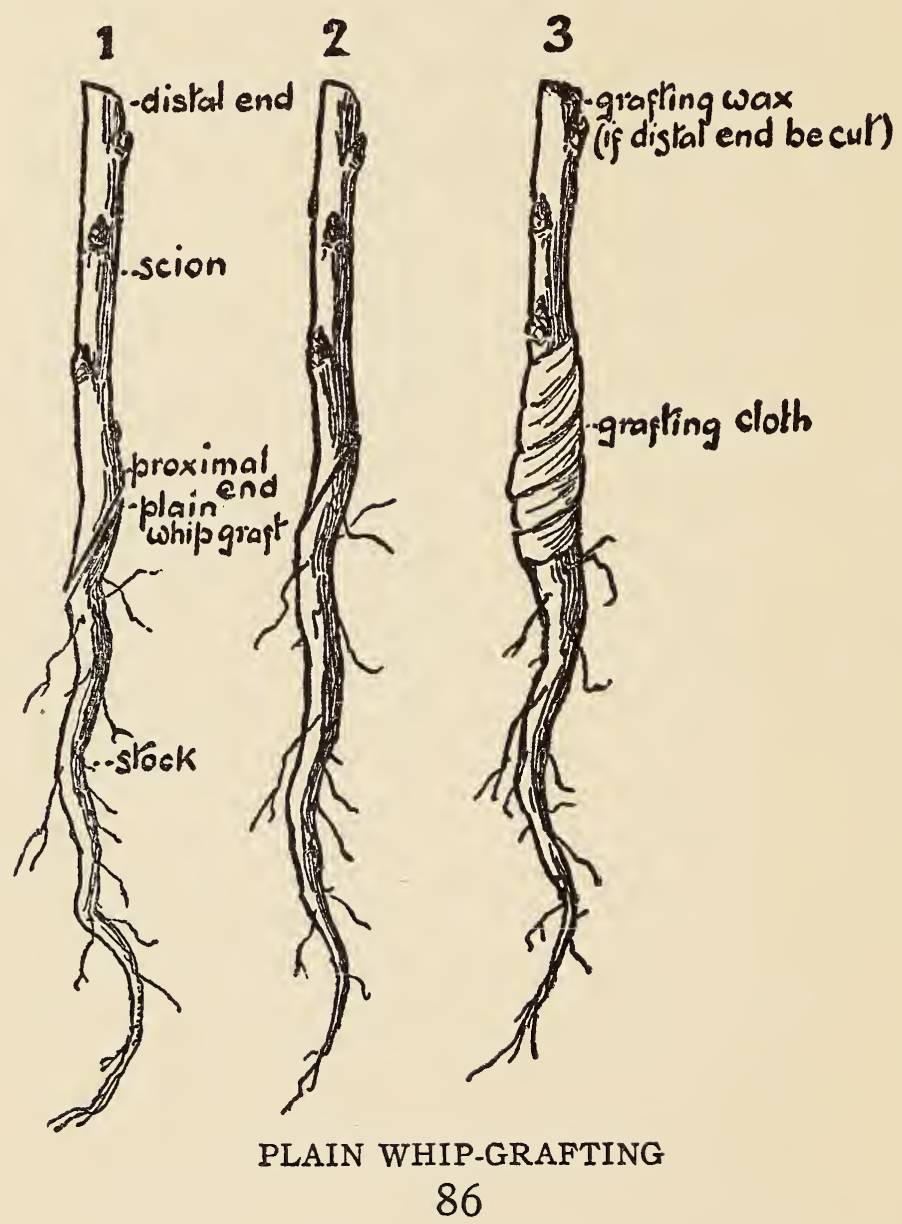


and on the distal end of stock that just match each other. Place them so the cam-
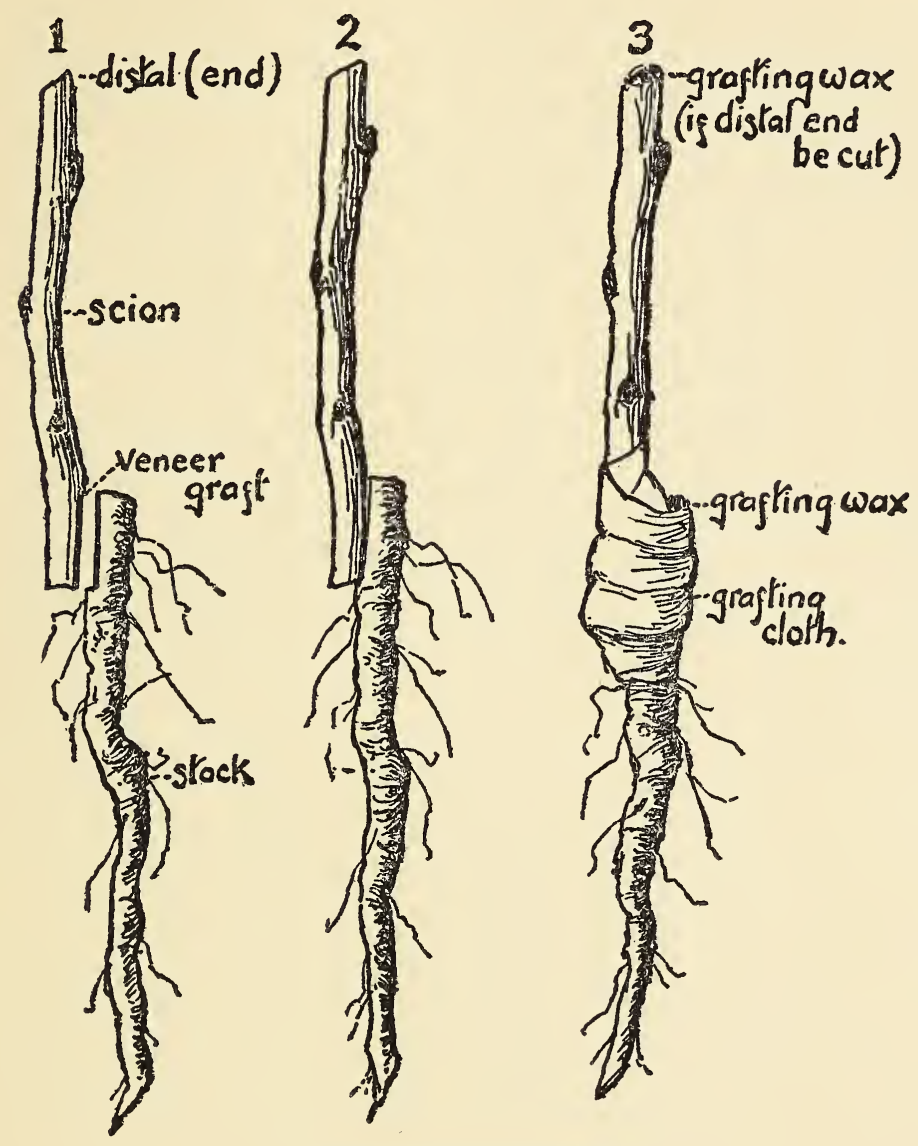

VENEER GRAFTING

bium layers of the stock and the scion coincide, and bind firmly with graftingcloth. 
For Veneer Grafting: Remove a shaving of bark through the cambium layer, about one inch long, from both the stock and the scion. Make a short transverse cut at the base of each vertical cut. Have the cambium layers of the stock and the scion coincide. Bind firmly with graftingcloth, and store in damp moss or sand in a cool moist place till spring.

A modified form of veneer grafting, called approach grafting, is used on plants in leaf. In this case the stocks and scions remain on their own roots until union takes place. 


\section{LESSON V}

For Planting Root Grafts: Prepare the land by plowing or spading thoroughly and harrow or rake it so the surface is nearly smooth. If the ground be rich, no fertilizer is needed. Stretch a line where the first row is desired. Press the spade or dibble into the ground beneath the line. Move it slightly to increase the size of the opening. Remove the tool and insert the root graft, placing it in the soil well below the union, to encourage adventitious roots from the scion and to prevent adventitious shoots from the stock. Press the soil firmly about it with the heel or dibble and continue, putting in the root grafts every six or eight inches, under the line. Put the rows four feet apart if to be cultivated with a horse and three feet if by hand only. Two persons can work to the best advantage, one using the spade or dibble while the other carries the 89 
90 HOW TO MAKE SCHOOL GARDENS bundle of root grafts and inserts them. Hardy cuttings are planted the same way. If the row be long, the line should be pinned down in several places to keep it straight. 


\section{Budding}





\section{CHAPTER VI}

\section{BUdDING}

For this work it is best to grow a few peach trees from the seeds, which have been saved the previous year and planted either in the fall or cracked and planted in the spring. By September, the trees will be large enough and ready to bud. A few days before budding is to take place it is well to go about and trim off the leaves for five or six inches from the ground. This should not be done very long beforehand, as it will harden up the wood too rapidly. Budding should take place when the bark slips freely. Bud sticks should be cut from some well-known tree and the leaves trimmed off immediately, leaving about one-half inch of the stem of the leaf for a handlefor thebud. These sticks should be wrapped in moist cloth until 
94 HOW TO MAKE SCHOOL GARDENS

used. It is well to procure special budding knives, although any knife with a round point can be used.

For " $T$ " Budding: Make a cut through the bark about half around the tree on the north side and about two inches from the ground with a very sharp round-pointed $\mathrm{kn}$ ife Make a longitudinal cut about one inch long, cutting up to the horizontal cut already made. Open slightly the lips with the point of the knife, or spatula if you have one. Cut out a

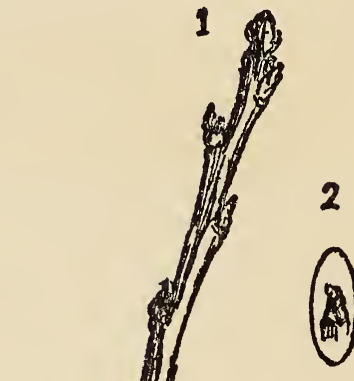
bud from the bud stick, putting the knife about one-fourth of an inch below the bud, taking out the bud with little or no wood. Use the handle of the bud to insert it into 
the cut already made in the stock. Take a piece of damp raffia about six inches long

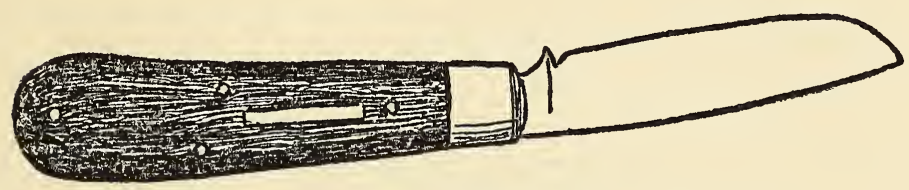

A CHEAP, DURABLE BUDDING KNIFE

and place the centre of it just below the bud. Bring it around back of the stock, cross it, and bring it up over the bud, crossing it again. Repeat this operation

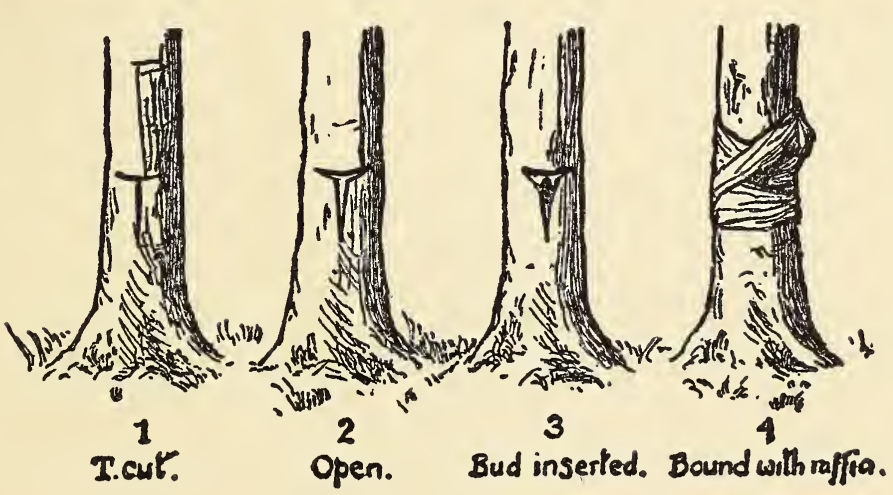

and tie with a single knot on the south side. In about ten days this raffia should be cut to prevent its girdling the tree. The following spring, if the bud is living, the 
96 HOW TO MAKE SCHOOL GARDENS

stock should be cut off just above where the bud is inserted, so that the main trunk will come from the bud. All other sprouts should be removed.

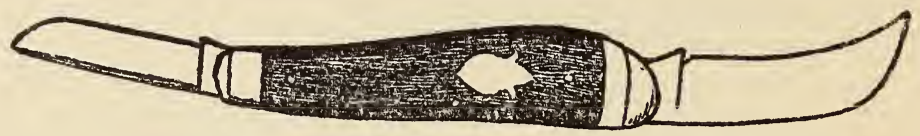

A COMBINATION BUDDING AND PRUNING KNIFE 


\section{School Garden Bibliography}





\section{CHAPTER VII}

\section{School Garden Bibliography}

Report of the School Garden Session of the American Park and Outdoor Art Association, including the following papers: "The School Garden as a Phase of Industrial Work," by W. A. Baldwin, Principal of the State Normal School at Hyannis, Mass. "Boston Sand Gardens," by Miss Ellen M. Tower, of Lexington, Mass. "The School Gardens at the School of Horticulture," by H. D. Hemenway, Director of the School of Horticulture, Hartford, Conn. "The National Cash Register Boys' Gardens," by George A. Townsend, Jr., of Dayton, Ohio. "Some Neglected Millions," by Mr. Knight, New York City. "How We Reach Eighteen Thousand School Children in New York," by Professor John W. Spencer, of the Bureau of Nature-Study at Cornell University.

"Nature-Study for Children," by George F. Powell, Director of the School of Horticulture at Briar Cliff Manor, New York.

Address Charles M. Robinson, 65 So. Washington St., Rochester, N. Y. Price, 25 cents.

Report of the Commissioners appointed by the Legislature in 1899 to Investigate and Report upon the Methods of Procedure in this and 
other States and Countries in Giving Instruction in Manual Training and in the Theory and Art of Agriculture in the Public Schools. L. D. Hart, Commissioner, Madison, Wis.

Hand Book for the Iowa School Edition of I900, pages I75. "Rural School Improvements," Richard C. Barrett, Superintendent of Public Instruction.

Report of the Board of Trustees of Public Schools - of the District of Columbia for I898-99, Superintendent of Schools, Washington, D. C. "Vacation Schools," pages 49.

"Manual Training in Public Schools." Reprinted from a report of the Ontario Educational Association, 1901, by Professor James W. Robertson, Ottawa, Canada. Pages I 5 "The Rural Schools."

Annual Report of the Superintendent of Education of the Public Schools of Nova Scotia for I900, Halifax, Nova Scotia. "School Gardens." Pages 27.

Fifty-first Missouri Report of Public Schools, W: F. Carrington, State Superintendent, Jefferson City, Mo. "Nature-Study." Pages I 32.

Teachers' Manual for Elementary and High Schools. First Edition, I898. State of Nevada, Carson City, J. G. McCarthy, Superintendent. "NatureStudy." Pages 8r.

Manual of Elementary Course of Study for the Common Schools of Wisconsin. L. D. Harvey, State Superintendent. "Nature Lessons." Pages 89.

"The Hand Book for Planning and Planting Small Home Grounds," by Warren H. Manning. Published by the Stout Manual Training-School, Menomonie, Wis.

Manual of School Law, Nova Scotia, Igor. Com- 
mittee of Public Works and Mines, Halifax, Nova Scotia. Pages 66.

Fifty-second Annual Report of the Public Schools of the City of Worcester, Mass. Superintendent of Schools, Worcester, Mass. "Nature-Study and Garden Work." Pages 48.

"School Gardens at the School of Horticulture, Hartford, Conn." by H. D. Hemenway, Director of the School of Horticulture, read before Boston Meeting of the American Park and Outdoor Art Association. Published in Park and Cemetery, September, I902, 324 Dearborn Street, Chicago, Ills.

"Boys Trained for Citizenship," published in The World To-day, October, I902. I 53-I55 LaSalle Street, Chicago, Ills.

"Garden Movement for Schools," by Dick J. Crosby, Office of Experiment Stations, U. S. Department of Agriculture. Published in The World To-day, October, I902, I53-I55 LaSalle Street, Chicago, Ills.

"Farming Industry in the United States," published in The World To-day, September, I902, I 53-I 55 LaSalle Street, Chicago, Ills.

"School Gardening in the Boston Normal School." Published in Modern Methods, April, I902, New Eng. Pub. Co., Boston and Chicago.

"Flower Gardens in Public Schools," by Jessie M. Good. Published in "How to Grow Flowers," October, I 900; the Floral Publishing Co., Springfield, Ohio.

"The School Garden, State Normal School, Hyannis, Massachusetts," by Bertha Brown. Published in Fournal of Education, April, 1902. Boston, Mass. 
"School Gardens," by Henry Lincoln Clapp, Master George Putnam School. Reprinted from Education, May, I90 I, Roxbury, Mass. Magazine. Also reprinted in pamphlet form.

"The School Garden," published by State Normal School, Hyannis, Mass. Catalogue and Circular.

"Horticulture Education for Children," by Henry Lincoln Clapp, Principal of George Putnam School, Roxbury. Transactions of Massachusetts Horticultural Society for the year I 890 .

"School Gardens," by Henry Lincoln Clapp. Published in Appleton's Science Monthly," February, 1898 .

“A Public School Garden," by Henry Lincoln Clapp. Published in New England Magazine, June, 1902. "School Gardens," by Henry Lincoln Clapp. Published in Education, May and June, rgoz.

Report of the Committee on School Gardens and Children's Herbariums of the Massachusetts Horticultural Society, for the year I900, by Henry Lincoln Clapp, Chairman, Boston, Mass.

"Efforts of the Pupils of the Public Schools for Home and Public Improvement," by Carthage, Mo., Public Schools, March I, I902.

"Two Foreign Schools and Their Suggestions," by Daniel S. Sanford. Published in New England Magazine, May, I902. II33 Broadway, New York City.

Prizes awarded to the Sunday Post-Despatch Gardners. Published in St. Louis Post-Despatch, September 28, 1902, St. Louis, Mo.

"The School Garden." Published in the Evening Star, October 18, I902, Washington, D. C. "The Child Farmers of New York," by Louise Seymour Houghton. Published in Christian 
Work and Evangelist, October 25, 1902. New York City.

"The Country School and the Country Child," by O. J. Kern, County Superintendent of Schools, Rockford, Ills. Published in School News, September, I902. Taylorville and Chicago, Ills. "The Country School and the Country Child," by O. J. Kern, County Superintendent of Schools, Rockford, Ills. Published in School News, October, I902, Taylorville and Chicago, Ills. " The Country School and the Country Child," by O. J. Kern, County Superintendent of Schools, Rockford, Ills. Published in School News, November, I902. Taylorville and Chicago, Ills. "The Country School and the Country Child." Winnebago County, I1ls., Report.

Report of a Visit to the Centralized School of Ohio, by O. J. Kern, County Superintendent of Schools, Rockford, Winnebago County, Ills.

"School Gardens, Their Development and Functions," by Dick J. Crosby, Office of Experiment Stations U. S. Dept. Agriculture. Published in Outlook. August, 1902. With references.

Reports of the Committee on School Gardens and Children's Herbariums, of the Massachusetts Horticultural Society for the years I898, I 899 and rgor.

Bulletins Nos. I 2 I, I 60 and 205 of the Horticultural Division of Cornell University, Agriculture Experiment Station, Ithaca, N. Y.

National Cash Register Company. Published in Outdoor Art and Beautiful House Edition, June, I899, Dayton, Ohio.

Annual Distribution of Prizes for Outdoor Art and Landscape Gardening. Published by National 
Cash Register Company, June, 1902, Dayton, Ohio.

"Home Gardening Association." rgor, Cleveland, Ohio. Report.

"A Story of Home Gardens," by Starr Cadwallader, I902, Cleveland, Ohio. Pamphlet.

"How to Beautify Carthage," by L. E. Archias Seed Company, II3-II5 Main Street, Carthage, Mo. Pamphlet.

"The National Cash Register Company." Published in Social Service for January, I902. Published at 287 Fourth Avenue, New York City. Reports issued by the National Cash Register Company, of Dayton, Ohio.

"Report, Rules and Regulations adopted by the Park Commission, Dayton, Ohio, also Hints, Suggestions on Street and Decorative Planting, Maintenance of Trees, Shrubs, Lawns, etc," I901. "The Whittier School Garden." Published in The Southern Workman of November, I902. Published by Hampton Institute Press.

"Hampton Nature-Study Leaflet No. 7." Published by Hampton Institute Press, Hampton, $\mathrm{Va}$.

"Suggestions for Progressive and Correlative Nature-Study," by G. M. Carver, Tuskegee Normal and Industrial Institute, Tuskegee, Ala.

Report for I90 I of "Home Gardening Association," Cleveland, Ohio, by E. W. Haines, President.

Bulletins Nos. 62 and $7 \mathrm{I}$ of the Department of Agriculture of State of Pennsylvania.

Government Reports: Chapter XX.- "School Gardens ${ }_{i=1}$ U. S. Bureau of Education for 1898 and I899. 
Chapter XXXIV.-Extracts from Consular Report, U. S. Bureau of Education, 1899. Pamphlet.

Chapter XXVII.-Consular Reports, U. S. Bureau of Education, rgor. Pamphlet.

Chapter XV.- "Public Playgrounds and Vacation Schools," U. S. Bureau of Education, rgor. Pamphlet.

Chapter XXXIII.- "Methods of Instruction in Agriculture." U. S. Bureau of Education, I899. Pamphlet.

Chapter VI.- "Education in Central Europe," U. S. Bureau of Education, I899. Pamphlet.

"School Gardens," by U. S. Bureau of Education, 1900. Washington, D. C. Bulletin.

"The Physician's Influence in Vacation Schools," by Helen C. Putnam, M. D. Reprinted from the Bulletin of the American Academy of Medicine, October, 1900. Pamphlet.

"School Gardens in Cities," by Helen C. Putnam, M. D. Lecture given before the Rhode Island Normal School, April I, I902. Providence, R. I. Pamphlet.

"Agricultural and Rural Life in Public Schools," by Willet M. Hays, Professor of Agriculture, University of Minnesota, rgor. St. Anthony Park, Minn. Bulletin.

“'School Gardens,' by F. M. Powell, M. D., Glenwood, Iowa. Read at the Iowa State Horticultural Society, Des Moines, Iowa, December I4, 1899. Report.

"Farming in the City." Philadelphia Vacant Lot Cultivation Association, Philadelphia, Pa., I90I. Report.

"Self-Help for Those Who Can't Work in the 


\section{IO6 HOW TO MAKE SCHOOL GARDENS}

Usual Business." Philadelphia Vacant Lot Cultivation Association, Philadelphia, Pa., I90I. Report.

Second Annual Report of the Vacation School Committee, Hartford, Conn., I902.

"Beautifying School Yards." Country Life in America, April, I902, New York City.

"Preparing School Gardens." Home and Flowers, January I903, Springfield, Ohio.

"A Model Township Conducted by Canadian Boys." The Seattle Post Intelligencer, October 5, I902.

“Training for Citizenship." Published in Educational Journal of Western Canada, December, I902. Victoria, B. C.

"School Gardens in Rochester, New York," Country Life in America, April, r902. Doubleday, Page \& Company, 34 Union Square, East, New York City.

"The Planting of School Grounds," in Country Life in America, April, I902. Published by Doubleday, Page \& Company, 34 Union Square, East, New York.

"School Gardens." Country Life in America, March, I903.

“A Successful School Garden," Country Life in America, March, 1903.

"School Gardens (Department of Agriculture work), January 4, I903. The Washington Times, Washington, D. C.

Report for I902. The Home Garden Association, Cleveland, Ohio.

School News, Taylorville, Ills. Nearly every issue contains subjects on school gardens.

"School Gardens," by F. M. Powell, M. D., Supt. 
Iowa Institution for Feeble-Minded Children, Glenwood, Iowa. Pamphlet, I902.

A "Children's Farm" in New York. The Alumni Association of the Philadelphia Normal School. Association Letter for October, I902, pages 7 .

Second Annual Report of the School of Horticulture, Hartford, Conn. 







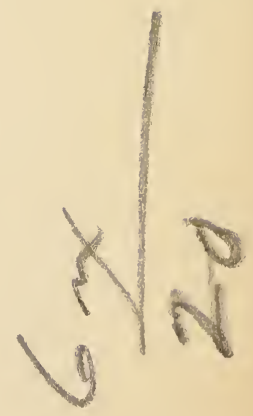



SMITHSONIAN INSTITUTION LIBRARIES

|| ||||||||||||||||||||||||||||||||||||||||||||||||||||||||||||||||||||||

3. $9088 \quad 00778 \quad 4333$ 